\title{
Copper-free click enabled triazabutadiene for biorthogonal protein functionalization
}

\author{
Supporting Information
}

Anjalee N. Wijetunge ${ }^{\dagger}$ Garrett J. Davis,${ }^{\dagger}$ Mehrdad Shadmehr,

Julia A. Townsend, Michael T. Marty, and John C. Jewett*

Department of Chemistry and Biochemistry

University of Arizona, Tucson, AZ 85721

$\dagger$ authors contributed equally

*corresponding author. E-mail: jjewett@email.arizona.edu 


\section{Table of Contents}

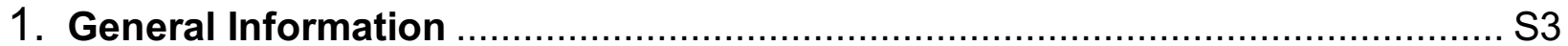

2. Synthetic Procedures and Characterization (1-4, S1-5) ............................. $44-7$

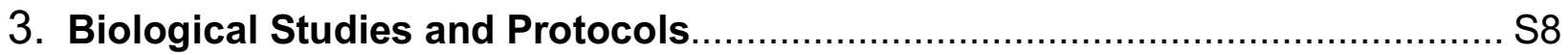

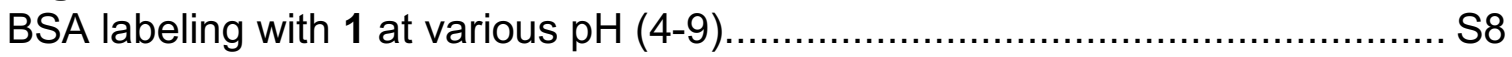

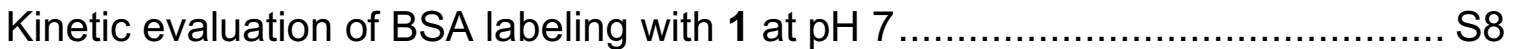

Figure S1: Plot of BSA fluorescence vs Time following treatment with 1 .........S9

Quantification of gel band fluorescence with Image J for kinetic evaluation........ S9

BSA labeling with 1 with resorcinol competition ........................................... 10

Reduction of 1 labeled BSA with sodium dithionite ...................................... S10

Treatment of BSA with 1 in the presence of excess cysteine ......................... S10

Treatment of DBCO-modified BSA with excess cysteine ............................... S10

Figure S2: Gel of BSA treated with cysteine before and after treatment of 1 .. S11

Figure S3: BSA band fluorescence upon cysteine treatment ...................... S11

Quantification of gel band fluorescence with ImageJ after cysteine treatment S12 SDS-PAGE analysis of MSP1D1T2(-) labeling with 1 and Alexa Fluor azide .. S12 Labeling of MSP1D1T2(-) with 1 and $\mathrm{PEG}_{2}$ - Biotin azide ............................ S13 MSP1D1T2(-) Sample analysis by Native Mass Spectrometry ..................... S14

Figure S4: MSP1D1T2(-) Sample analysis by Native Mass Spectrometry...... S14

Extraction of hen egg proteins from commercial chicken eggs ...................... S15

Treatment of Hen Egg protein extract with $1(\mathrm{pH} \mathrm{6.5)} \mathrm{\ldots ...............................} \mathrm{S15}$

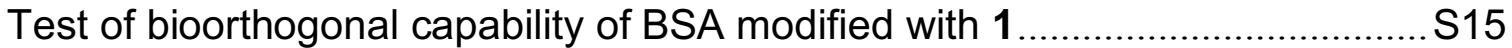

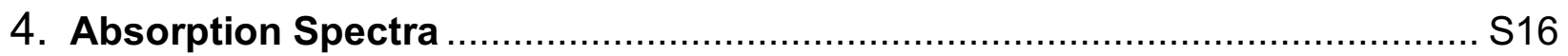

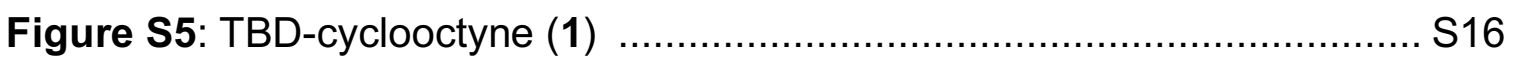

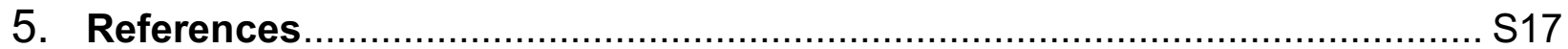

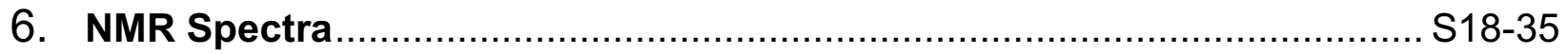




\section{General Information}

\section{Synthetic \& Characterization}

The chemicals including 4-aminobenzoic acid, conc. $\mathrm{HCl}$, sodium nitrite, sodium azide, thionyl chloride, potassium tert-butoxide, 1-tert-butyl imidazole, methyl iodide, $\mathrm{LiOH}$, diisopropylethylamine, $\mathrm{N}$-hydroxysuccinimide, HATU, triethyl amine, D-biotin, 1-Ethyl-3(3-dimethylaminopropyl)carbodiimide (EDC) and all the solvents and chromatography materials including silica and basic alumina were purchased commercially and used as received. 2-(2-(2-azidoethoxy)ethoxy)ethan-1-amine (CAS\# 166388-57-4) was purchased from Lumiprobe and Dibenzocyclooctyne amine $\left(\mathrm{DBCO}-\mathrm{NH}_{2}\right)$ was purchased from Click Chemistry Tools (Catalog number: A103-25).

NMR spectra were taken either on a Bruker AVANCE III $400 \mathrm{MHz}$ NMR, Bruker AVANCE DRX $500 \mathrm{MHz}$ NMR or Bruker NEO $500 \mathrm{MHz}$ NMR Spectrometer for ${ }^{1} \mathrm{H}$ and ${ }^{13} \mathrm{C}$ NMR and referenced with residual solvent peaks at $7.26 \mathrm{ppm}$ and $77.0 \mathrm{ppm}$ for $\mathrm{CDCl}_{3}, 2.50$ and 39.5 for DMSO- $d_{6}$. Coupling on the NMR spectra is expressed in Hertz $(\mathrm{Hz})$, chemical shifts in ppm, with abbreviations for multiplicities as $s=$ singlet, $d=$ doublet, $t=$ triplet, $q$ $=$ quartet, $p=$ pentet, $m=$ multiplet. Mass spectra were obtained using solariX 2XR 9.4T FTICR instrument. Mass spectral analysis was performed on a Bruker ICR ESI. Infrared spectra were obtained using a Thermo Fisher Scientific Nicolet IS50R FT-IR Spectrometer. The transmission mode was attenuated total reflectance (ATR), using a Spectra-Tech Thunderdome germanium crystal ATR accessory. The detector was a liquid nitrogen cooled high sensitivity MCT-A detector. The FT-IR signals are reported as $\mathrm{w}=$ weak, $\mathrm{m}=$ medium $\mathrm{s}=$ strong, $\mathrm{br}=$ broad.

\section{Biochemical}

Buffers were made appropriately using commercially purchased salts and nanopure water. They were checked for proper $\mathrm{pH}$ prior to experimental use. BSA stocks were made from commercially purchased lyophilized powder (Sigma Aldrich, CAS: 9048-468). MSP1D1T2(-) protein was expressed and purified by methods previously described. ${ }^{1}$ Modified protein samples and controls were analyzed by SDS-PAGE on a $12 \%$ acrylamide resolving gel. Samples were treated with 1:1 ratio of $2 \mathrm{X}$ Laemmli sample buffer from Sigma Aldrich (Item S3401) containing 4\% SDS, 20\% glycerol, 10\% 2mercaptoethanol, $0.004 \%$ bromophenol blue, and $0.125 \mathrm{M}$ Tris $\mathrm{HCl} \mathrm{pH} \mathrm{6.8.} \mathrm{Alexa} \mathrm{fluor}{ }^{\mathrm{TM}}$ 488 azide was purchased from Thermo-Fisher Scientific (Catalog number: A10266). Fluorescent imaging was performed with a ChemiDoc ${ }^{\mathrm{TM}}$ MP scanner (BioRad) using a $488 \mathrm{~nm}$ laser line (Pharos FX Plus Molecular Imager) with a $535 \mathrm{~nm}$ filter. Coomassie staining was imaged using the same scanner. 


\section{Synthetic Procedures and Characterization}

\section{4-azido benzoic acid - (SI-1)}<smiles>Nc1ccc(C(=O)O)cc1</smiles>

SI-1 was synthesized as an off-white solid $(0.546 \mathrm{~g}, 93 \%)$ according to the previously reported methods. ${ }^{2}{ }^{1} \mathrm{H}$ NMR $\left(400 \mathrm{MHz}, \mathrm{DMSO}-d_{6}\right) \delta 12.94(\mathrm{~s}$, $1 \mathrm{H}), 7.95(\mathrm{~d}, J=8.1 \mathrm{~Hz}, 2 \mathrm{H}), 7.21(\mathrm{~d}, J=8.2 \mathrm{~Hz}, 2 \mathrm{H}) .{ }^{13} \mathrm{C}$ NMR $(100 \mathrm{MHz}$, DMSO-d $\left.d_{6}\right) \delta 166.53,143.92,131.19,127.27,119.15$.

methyl 4-azidobenzoate - (2)<smiles>COC(=O)c1ccc(N)cc1</smiles>

2 was synthesized as a brownish yellow crystalline solid $(0.280 \mathrm{~g}, 88 \%)$ according to the previously reported methods. ${ }^{2}{ }^{1} \mathrm{H}$ NMR $(400 \mathrm{MHz}$, DMSO$\left.d_{6}\right) \delta 8.02-7.91(\mathrm{~m}, 2 \mathrm{H}), 7.32-7.20(\mathrm{~m}, 2 \mathrm{H}), 3.84(\mathrm{~s}, 3 \mathrm{H}) .{ }^{13} \mathrm{C}$ NMR $(100$ $\left.\mathrm{MHz}, \mathrm{DMSO}-d_{6}\right) \delta 165.45,144.38,131.04,126.02,119.33,52.10$.

\section{3-(tert-butyl)-1-methyl-1 H-imidazol-3-ium iodide- (3)}

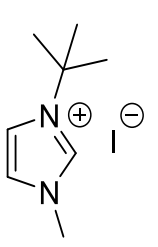

$t$-butyl imidazole $(0.124 \mathrm{~g}, 1.00 \mathrm{mmol})$ was dissolved in $2 \mathrm{~mL}$ of acetonitrile. Methyl iodide $(0.178 \mathrm{~g}, 1.25 \mathrm{mmol})$ was added to this dropwise at $0{ }^{\circ} \mathrm{C}$. The reaction was stirred overnight at RT. The solvent was evaporated under vacuum and the product (3) was isolated as a white powder in quantitative yields. The above procedure was a slight modification of an existing procedure. ${ }^{3}{ }^{1} \mathrm{H}$ NMR $(400 \mathrm{MHz}$, Chloroform-d) $\delta 9.97(\mathrm{q}, J=1.4 \mathrm{~Hz}, 1 \mathrm{H})$, $7.58(\mathrm{t}, J=1.9 \mathrm{~Hz}, 1 \mathrm{H}), 7.51(\mathrm{t}, J=1.9 \mathrm{~Hz}, 1 \mathrm{H}), 4.11(\mathrm{~s}, 3 \mathrm{H}), 1.67(\mathrm{~s}, 9 \mathrm{H})$.

${ }^{13} \mathrm{C}$ NMR (100 MHz, Chloroform-d) $\delta 135.20,123.85,119.48,60.39,36.91,30.04$. 
Methyl 4-((E)((E)-1-(tert-butyl)3-methyl-1,3-dihydro-2H-imidazol-2-ylidene)triaz-1en-1-yl)benzoate - (SI-2)

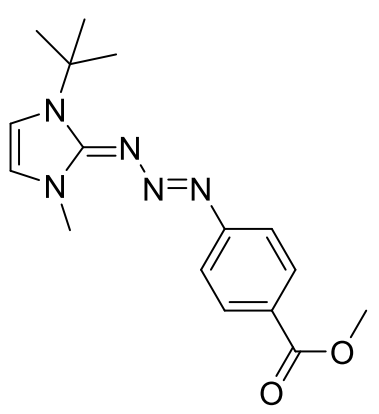

In a flame-dried round bottom flask, azide $2(0.450 \mathrm{~g}, 2.54 \mathrm{mmol}$, 1 equiv) and imidazolium 3 ( $0.798 \mathrm{~g}, 3.00 \mathrm{mmol}, 1.2$ equiv) were dissolved in anhydrous THF (10 mL). To the solution was added $t$-BuOK $\left(0.560 \mathrm{~g}, 5.00 \mathrm{mmol}, 2\right.$ equiv) in one portion at $0^{\circ} \mathrm{C}$ while stirring. The reaction was allowed to warm to RT slowly removing the ice bath and stirred for $3 \mathrm{~h}$. The solution was filtered using a filter paper, washing with $\mathrm{CH}_{2} \mathrm{Cl}_{2}$ and the solvent was evaporated to provide a crude product. The mixture was purified using a basic alumina column (Hexanes : Ethyl Acetate $\left.=1: 2, \mathrm{R}_{\mathrm{f}}=0.3\right)$ to afford the product $(\mathbf{S I}-2)$ as a bright yellow solid $(0.607 \mathrm{~g}, 77 \%)$. ${ }^{1} \mathrm{H}$ NMR $\left(400 \mathrm{MHz}\right.$, DMSO- $\left.d_{6}\right) \delta 7.91-7.84(\mathrm{~m}, 2 \mathrm{H}), 7.45-7.36$ $(\mathrm{m}, 2 \mathrm{H}), 7.18(\mathrm{~d}, J=2.6 \mathrm{~Hz}, 1 \mathrm{H}), 7.03(\mathrm{~d}, J=2.5 \mathrm{~Hz}, 1 \mathrm{H}), 3.82(\mathrm{~s}, 3 \mathrm{H}), 3.75(\mathrm{~s}, 3 \mathrm{H}), 1.62$ (s, 9H). ${ }^{13} \mathrm{C}$ NMR $(100 \mathrm{MHz}$, DMSO-d $) \delta 166.19,156.90,151.03,130.16,124.42,119.82$, 118.21, 113.45, 58.09, 51.73, 38.46, 28.27. IR (ATR) 1708 (m), $1597(\mathrm{w}), 1521(\mathrm{~m}), 1347$ (m), $1268(\mathrm{~m}), 1196(\mathrm{~m}), 1150(\mathrm{~s}), 1113(\mathrm{~m}), 1099(\mathrm{w}), 851(\mathrm{w}), 773(\mathrm{~m})$. HRMS (ESI) $\mathrm{m} / \mathrm{z}$ : $[\mathrm{M}+\mathrm{H}]+$ calculated for $\mathrm{C}_{16} \mathrm{H}_{21} \mathrm{~N}_{5} \mathrm{O}_{2} 316.1773$; found value 316.1765 .

\section{4-((E)-((E)-1-(tert-butyl)-3-methyl-1,3-dihydro-2H-imidazol-2-ylidene)triaz-1-en-1- yl)benzoate lithium (I) - (SI-3)}

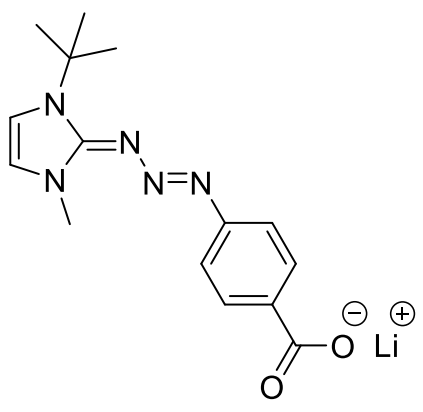

To methyl ester (SI-2) (60 mg, $0.19 \mathrm{mmol}, 1$ equiv) charged in a round bottom flask was added a $10 \% \mathrm{LiOH}$ suspension in water ( $10 \mathrm{mg}, 100 \mu \mathrm{L}, 0.42 \mathrm{mmol}, 2.2$ equiv). A mixture of $5 \mathrm{~mL}$ of THF and $5 \mathrm{~mL}$ of $\mathrm{DI} \mathrm{H}_{2} \mathrm{O}$ was added to the mixture. The reaction was heated to $80^{\circ} \mathrm{C}$ in an oil bath while stirring vigorously. After $2 \mathrm{~h}$ the reaction was stopped removing from the oil bath, and the organic layer was evaporated using a vacuum pump. Remaining water was removed by blowing air on the reaction mixture. The crude product mixture (SI-3) was clean enough and carried on to the next step without further purification.

${ }^{1} \mathrm{H}$ NMR $\left(500 \mathrm{MHz}\right.$, DMSO- $\left.\mathrm{d}_{6}\right) \delta 7.83-7.80(\mathrm{~m}, 2 \mathrm{H}), 7.25-7.21(\mathrm{~m}, 2 \mathrm{H}), 7.08(\mathrm{~d}, J=2.6$ $\mathrm{Hz}, 1 \mathrm{H}), 6.92(\mathrm{~d}, J=2.6 \mathrm{~Hz}, 1 \mathrm{H}), 3.73(\mathrm{~s}, 3 \mathrm{H}), 1.61(\mathrm{~s}, 9 \mathrm{H}) \cdot{ }^{13} \mathrm{C}$ NMR $(126 \mathrm{MHz}$, DMSOd6) $\delta 169.38,152.93,151.61,136.91,129.76,118.79,117.62,112.75,57.58,38.60$, 28.18. IR (ATR) $1596(\mathrm{~m}), 1557(\mathrm{w}), 1524(\mathrm{~m}), 1453(\mathrm{w}), 1398(\mathrm{~m}), 1353(\mathrm{~m}), 1277(\mathrm{~m})$, $1244(w), 1233(w), 1192(s), 1162(m), 1100(w), 869(w), 844(w), 834(w), 818(w), 795$ $(\mathrm{m}), 775(\mathrm{w}), 755(\mathrm{w}), 750(\mathrm{w})$. HRMS (ESI) m/z: $[\mathrm{M}+2 \mathrm{H}]+$ calculated for $\mathrm{C}_{15} \mathrm{H}_{18} \mathrm{~N}_{5} \mathrm{O}_{2}{ }^{-}$ 302.1617; found value 302.1613. 
2,5-dioxopyrrolidin-1-yl 4-((E)-((E)-1-(tert-butyl)-3-methyl-1,3-dihydro-2H-imidazol2-ylidene)triaz-1-en-1-yl)benzoate - (4)

The crude SI-3 (all from previous experiment) was

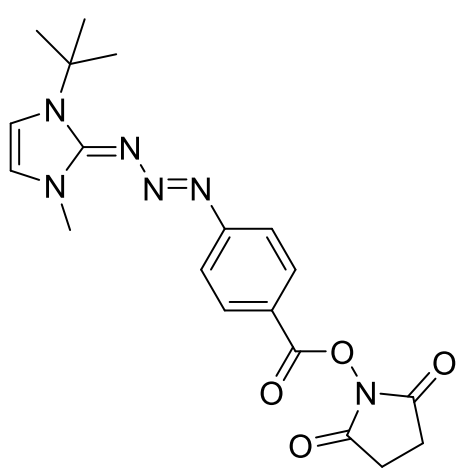
dissolved in anhydrous $\mathrm{CH}_{2} \mathrm{Cl}_{2}(20 \mathrm{~mL})$ sonicating if needed. To this mixture was added a small amount $(30 \mathrm{mg})$ of anhydrous $\mathrm{MgSO}_{4}$. Further, diisopropylethylamine (100 $\mu \mathrm{L}, 0.56 \mathrm{mmol}, 2.9$ equiv), $N$-hydroxysuccinimide $(50 \mathrm{mg}$, $0.43 \mathrm{mmol}, 2.3$ equiv) and finally HATU $(80 \mathrm{mg}, 0.21 \mathrm{mmol}$, 1.1 equiv) were added in order. The reaction was stirred overnight (16 h). The reaction was filtered, evaporated and the product formation was confirmed by taking a crude ${ }^{1} \mathrm{H}$ NMR in DMSO. The NHS-ester, 4, was carried on to the next step without further purification. ${ }^{1} \mathbf{H}$ NMR $(400 \mathrm{MHz}$, DMSO- $\left.d_{6}\right) \delta 7.97(\mathrm{~d}, 2 \mathrm{H}), 7.50(\mathrm{~d}, 2 \mathrm{H}), 7.25(\mathrm{~d}, 1 \mathrm{H}), 7.10$ (d, 1H), $3.77(\mathrm{~s}, 3 \mathrm{H}), 2.88(\mathrm{~s}, 4 \mathrm{H}), 1.63(\mathrm{~s}, 9 \mathrm{H})$.

\section{TBD-cyclooctyne (1)}

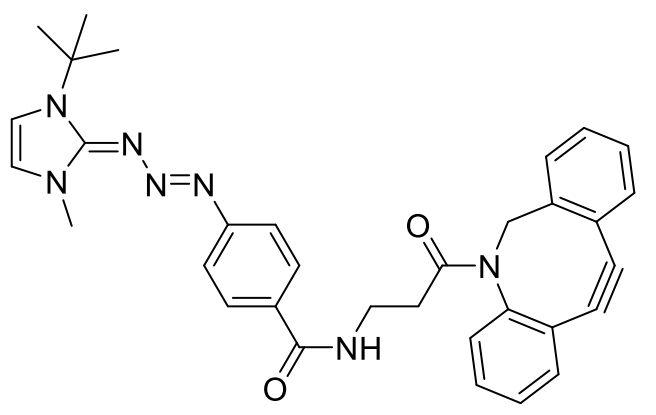

Assuming the complete conversion of SI-2 to 4 based on the $\mathrm{H}$ NMR, a crude solution of TBDNHS (4) $(76 \mathrm{mg} / \mathrm{mL}, 0.19 \mathrm{M})$ was prepared in anhydrous $\mathrm{CH}_{2} \mathrm{Cl}_{2}$. To a flame dried round bottomed flask was added DBCO-NH $2(12.6 \mathrm{mg}$, $0.045 \mathrm{mmol}, 1$ equiv) dissolved in $3 \mathrm{~mL}$ of anhydrous $\mathrm{CH}_{2} \mathrm{Cl}_{2}$. To this was added triethyl amine (5.4 $\mu \mathrm{L}, 0.045 \mathrm{mmol}, 1$ equiv) and a small amount $(30 \mathrm{mg})$ of anhydrous $\mathrm{MgSO}_{4}$. To this mixture, added was $(237 \mu \mathrm{L}, 0.045 \mathrm{mmol}, 1$ equiv) of the $76 \mathrm{mg} / \mathrm{mL}$ solution of 4 . The reaction was stirred 16 hours and then filtered, washing with $\mathrm{CH}_{2} \mathrm{Cl}_{2}$, and evaporated under vacuum. The crude product was purified using a basic alumina column and a solvent gradient. $\mathrm{CH}_{2} \mathrm{Cl}_{2}$ : ether $=4: 1$ and $\mathrm{CH}_{2} \mathrm{Cl}_{2}$ : ether $1: 1$ was used to get rid of non - polar impurities as the product stuck on the baseline. Then $2 \% \mathrm{MeOH}: \mathrm{CH}_{2} \mathrm{Cl}_{2}$ was used, and the product came off at $R_{f}=0.3$. However, this had 2 other $U V$ active spots when stained with $\mathrm{I}_{2}$. A trituration was done with $\mathrm{CH}_{2} \mathrm{Cl}_{2}$ and hexanes as an additional purification step. A yellow precipitate crashed out from the solution and was filtered to provide pure 1 (8.3 $\mathrm{mg}, 33 \%$ yield over 3 steps). The compound was stable in a solution of DMSO- $d_{6}$ for 5 months at $0^{\circ} \mathrm{C}$.

${ }^{1} \mathrm{H}$ NMR (500 MHz, DMSO-d $)$ ס $8.11(\mathrm{t}, \mathrm{J}=5.6 \mathrm{~Hz}, 1 \mathrm{H}), 7.67-7.65(\mathrm{~m}, 1 \mathrm{H}), 7.64-7.59$ $(\mathrm{m}, 3 \mathrm{H}), 7.52-7.47(\mathrm{~m}, 1 \mathrm{H}), 7.47-7.42(\mathrm{~m}, 2 \mathrm{H}), 7.42-7.38(\mathrm{~m}, 1 \mathrm{H}), 7.38-7.33(\mathrm{~m}$, $1 \mathrm{H}), 7.33-7.30(\mathrm{~m}, 2 \mathrm{H}), 7.30-7.27(\mathrm{~m}, 1 \mathrm{H}), 7.15(\mathrm{~d}, J=2.6 \mathrm{~Hz}, 1 \mathrm{H}), 7.00(\mathrm{~d}, J=2.5$ $\mathrm{Hz}, 1 \mathrm{H}), 5.07(\mathrm{~d}, J=14.0 \mathrm{~Hz}, 1 \mathrm{H}), 3.74(\mathrm{~s}, 3 \mathrm{H}), 3.64(\mathrm{~d}, J=14.0 \mathrm{~Hz}, 1 \mathrm{H}), 3.39-3.33(\mathrm{~m}$, $1 \mathrm{H}), 3.14-3.07(\mathrm{~m}, 1 \mathrm{H}), 2.58-2.51(\mathrm{~m}, 1 \mathrm{H}), 2.01-1.92(\mathrm{~m}, 1 \mathrm{H}), 1.61(\mathrm{~s}, 9 \mathrm{H}) .{ }^{13} \mathrm{C}$ NMR $(126$ $\left.\mathrm{MHz}_{\mathrm{CDCl}}\right)$ $\delta$ 170.42, 166.03, 151.59, 151.31, 148.51, 132.53, 129.77, 129.63, 129.03, 
$128.30,128.15,128.03,127.80,126.90,125.30,122.58,121.49,119.51,118.15,114.40$, 113.35, 108.20, 57.96, 54.80, 38.46, 35.68, 34.25, 28.21. IR (ATR) $2157(\mathrm{w}), 1649(\mathrm{~m})$, $1601(\mathrm{w}), 1525(\mathrm{~m}), 1483(\mathrm{~m}), 1449(\mathrm{w}), 1414(\mathrm{w}), 1397(\mathrm{w}), 1371(\mathrm{~m}), 1356(\mathrm{~m}), 1323$ (w), $1276(\mathrm{~s}), 1245(\mathrm{w}), 1157(\mathrm{~s}), 1105(\mathrm{~s}), 1009(\mathrm{w}), 945(\mathrm{w}), 856(\mathrm{w}), 770(\mathrm{~m}), 753(\mathrm{~m})$. HRMS (ESI) m/z: [M+ H]+ calculated for $\mathrm{C}_{33} \mathrm{H}_{33} \mathrm{~N}_{7} \mathrm{O}_{2} 560.2774$; found value 560.2755 .

2,5-dioxopyrrolidin-1-yl 5-((3aS,4S,6aR)-2-oxohexahydro-1H-thieno[3,4-d]imidazol4-yl)pentanoate (SI-4)

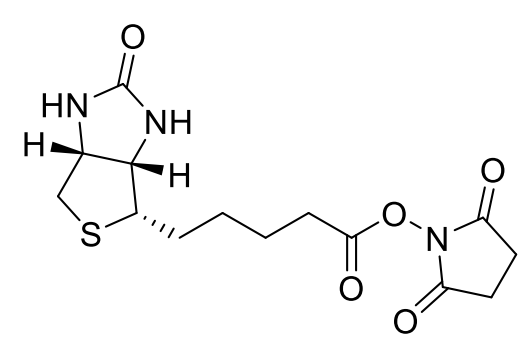

SI-4 was synthesized as a white solid $(0.952 \mathrm{~g}, 93 \%)$ according to the previously reported methods. ${ }^{4}{ }^{1} \mathrm{H}$ NMR $\left(400 \mathrm{MHz}, \mathrm{DMSO}-d_{6}\right) \delta 6.42(\mathrm{~s}, 1 \mathrm{H}), 6.36(\mathrm{~s}, 1 \mathrm{H}), 4.30(\mathrm{~m}$, $1 \mathrm{H}), 4.14(\mathrm{~m}, 1 \mathrm{H}), 3.10(\mathrm{~m}, 1 \mathrm{H}), 2.91-2.82(\mathrm{~m}, 1 \mathrm{H}), 2.81$ $(\mathrm{s}, 4 \mathrm{H}), 2.76-2.63(\mathrm{~m}, 2 \mathrm{H}), 2.58(\mathrm{~d}, J=12.4 \mathrm{~Hz}, 1 \mathrm{H}), 1.64$ (m, 3H), $1.57-1.35(\mathrm{~m}, 3 \mathrm{H}) .{ }^{13} \mathrm{C}$ NMR (100 MHz, DMSOd6) $\delta 170.24,168.91,162.66,60.98,59.15,55.21,29.98$,

$27.82,27.56,25.43,24.29$.

$\mathrm{N}$-(2-(2-(2-azidoethoxy)ethoxy)ethyl)-5-((3aS,4S,6aR)-2-oxohexahydro-1Hthieno[3,4-d] imidazol-4-yl)pentanamide (SI-5)

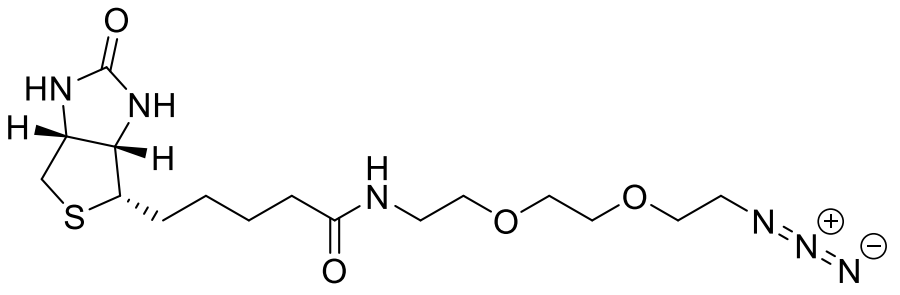

A modification of an existing protocol was followed. ${ }^{5}$ To biotin-NHS (SI-4) (50 mg, $0.15 \mathrm{mmol}, 1$ equiv) dissolved in dry DMF $(5 \mathrm{~mL})$, added was triethyl amine $(40 \mu \mathrm{L}, 0.29 \mathrm{mmol}, 1.9$ equiv) and commercially available 2-(2-(2azidoethoxy)ethoxy)ethan-1-amine

( $38.33 \mathrm{mg}, 0.22 \mathrm{mmol}, 1.5 \mathrm{eq})$. The reaction was stirred overnight (16 h) and the solvent was evaporated. The resulting crude mixture was re-dissolved in $\mathrm{CH}_{2} \mathrm{Cl}_{2}$ and treated with aqueous $\mathrm{NaHCO}_{3}$. Next, the organic layer washed with brine, dried over $\mathrm{MgSO}_{4}$ and evaporated under vacuum. Pure compound (SI-5) was obtained as a yellow glassy solid in appearance. $(0.028 \mathrm{mg}, 47 \%)$. The spectral data matched with literature. ${ }^{6}$

${ }^{1} \mathrm{H}$ NMR $\left(400 \mathrm{MHz}, \mathrm{DMSO}-d_{6}\right) \delta 7.80(\mathrm{t}, J=5.6 \mathrm{~Hz}, 1 \mathrm{H}), 6.41(\mathrm{~s}, 1 \mathrm{H}), 6.34(\mathrm{~s}, 1 \mathrm{H}), 4.32$ $-4.27(\mathrm{~m}, 1 \mathrm{H}), 4.15-4.10(\mathrm{~m}, 1 \mathrm{H}), 3.61-3.58(\mathrm{~m}, 2 \mathrm{H}), 3.58-3.54(\mathrm{~m}, 2 \mathrm{H}), 3.54-3.50$ $(\mathrm{m}, 2 \mathrm{H}), 3.42-3.37(\mathrm{~m}, 4 \mathrm{H}), 3.21-3.16(\mathrm{~m}, 2 \mathrm{H}), 3.12-3.06(\mathrm{~m}, 1 \mathrm{H}), 2.84-2.79(\mathrm{~m}$, $1 \mathrm{H}), 2.60-2.55(\mathrm{~d}, J=12.4 \mathrm{~Hz}, 1 \mathrm{H}), 2.08-2.03(\mathrm{t}, J=7.4 \mathrm{~Hz}, 2 \mathrm{H}), 1.66-1.55(\mathrm{~m}, 1 \mathrm{H})$,

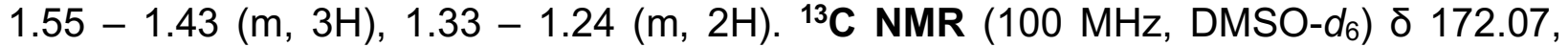
$162.66,69.59,69.54,69.23,69.13,61.01,59.16,55.39,49.97,39.82,38.40,35.07,28.16$, 28.01, 25.23. 


\section{Biological Studies and Protocols}

BSA labeling with 1 at various $\mathrm{pH}(4-9)$

In this experiment various buffers were used to preserve $\mathrm{pH}$. For the $\mathrm{pH} 4-5$ range, $0.1 \mathrm{M}$ citrate was used. For samples $\mathrm{pH} 6-8,0.1 \mathrm{M}$ PBS was used. $5 \mu \mathrm{L}$ of $1 \mathrm{mM}$ BSA was transferred to $172.8 \mu \mathrm{L}$ of respective buffer $(\mathrm{pH} 4-8)$. Two samples were made for each $\mathrm{pH}$. The first sample of each set was a control sample treated with $22.2 \mu \mathrm{L}$ of DMSO ( $\sim 11 \%$ by volume). The second sample for each $\mathrm{pH}$ unit was treated with $22.2 \mu \mathrm{L}$ of 1.8 $\mathrm{mM}$ 1. The final concentration of BSA in each sample was $25 \mu \mathrm{M}$ and the final concentration of 1 was $0.2 \mathrm{mM}$. All samples were incubated void of light for 3 hours and then treated with $20 \mu \mathrm{L}$ of $100 \mathrm{mM}$ resorcinol to quench the remaining aryl diazonium ion (final concentration of $9 \mathrm{mM}$ resorcinol). $30 \mu \mathrm{L}$ of each sample was then transferred to a new Eppendorf and treated with $1.2 \mu \mathrm{L}$ of $5 \mathrm{mM}$ Alexa Fluor azide to provide a concentration of $0.2 \mathrm{mM}$. Samples were further incubated void of light for 2 hours prior to being loaded on an SDS-PAGE.

Kinetic evaluation of BSA labeling with 1 at $\mathrm{pH} 7$

$10 \mu \mathrm{L}$ of $1 \mathrm{mM}$ BSA was diluted into $383.7 \mu \mathrm{L}$ of $0.1 \mathrm{M}$ PBS buffer $(\mathrm{pH} 7)$ in a $1.6 \mathrm{~mL}$ Eppendorf tube. Next, $6.35 \mu \mathrm{L}$ of $12.6 \mathrm{mM} 1$ was added to the solution to provide a final concentration of $25 \mu \mathrm{M}$ BSA and $0.4 \mathrm{mM}$ of 1 . Upon addition, aliquots of the reaction solution were removed at various time points of $5 \mathrm{~min}, 15 \mathrm{~min}, 30 \mathrm{~min}, 1$ hour, 2 hour, 4 hours and 6 hours. In addition, a second sample of equal BSA concentration was preincubated with $20 \mathrm{mM}$ resorcinol prior to the addition of 1 to act as the 0 min time point. Upon reaching each time point, $50 \mu \mathrm{L}$ of the reaction sample was transferred to a separate Eppendorf and treated with $2 \mu \mathrm{L}$ of $0.5 \mathrm{M}$ resorcinol to quench the diazonium reaction, providing a final resorcinol concentration of $\sim 19.2 \mathrm{mM}$. After the final time point, $10 \mu \mathrm{L}$ of each sample was removed to separate Eppendorf tubes and treated with $0.5 \mu \mathrm{L}$ of $5 \mathrm{mM}$ Alexa Fluor azide (Thermo-Fisher Scientific; Catalog number: A10266) to provide a final concentration of $0.4 \mathrm{mM}$. The click reaction proceeded for 2 hours prior to analysis on SDS-PAGE. 


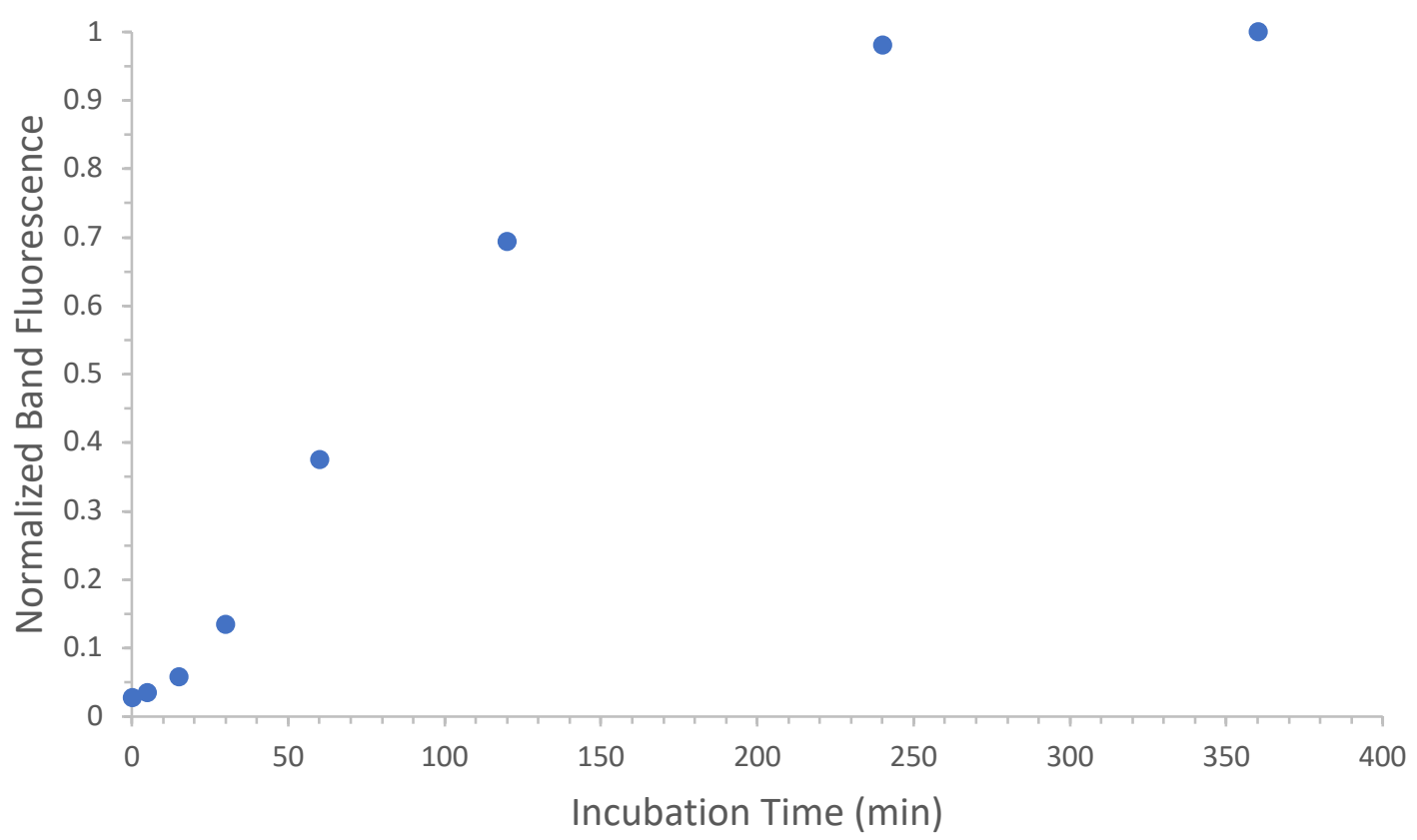

Figure S1. BSA treatment with $0.4 \mathrm{mM} 1$ across time points of 0 to 360 minutes. Following SDS-PAGE analysis, band fluorescence was quantified by ImageJ software and normalized to the Coomassie band density for each corresponding band. Normalized fluorescence was plotted as a function of time showing that after about 240 minutes (4 hours), fluorescence maxes out, indicating that the TBD has finished reacting.

\section{Quantification of gel band fluorescence with ImageJ Software for kinetic} evaluation

Using ImageJ software, the band intensities for both fluorescence and Coomassie scans were determined for each sample using the band integration tool. First, band fluorescence was normalized to the band with the highest fluorescence intensity amongst all samples by dividing all by its respective integration value. Next, we integrated the band intensity of the corresponding Coomassie stain. We then normalized the Coomassie band intensity to the highest band intensity providing a ratio between $0-1$. Lastly, each band fluorescence was divided by its respective Coomassie ration to normalize fluorescence intensity to the relative quantity of protein per band. This was done to accommodate for slight differences in protein concentrations between wells. Normalized fluorescent intensities were then plotted as a function of Time (SF1). 


\section{BSA labeling with 1 with resorcinol competition}

In two Eppendorf tubes, $1 \mathrm{mM}$ BSA was diluted to $50 \mu \mathrm{M}$ in $0.1 \mathrm{M}$ PBS buffer ( $\mathrm{pH} 7$ ). To the experimental sample, $10 \mu \mathrm{L}$ of $0.5 \mathrm{M}$ resorcinol stock was added to provide a final concentration of $20 \mathrm{mM}$. Both samples were then treated with $8 \mu \mathrm{L}$ of $12.6 \mathrm{mM} 1(0.4$ $\mathrm{mM})$ in a total volume of $250 \mu \mathrm{L}$. Samples were incubated void of light overnight ( 16 hours). $10 \mu \mathrm{L}$ of each sample was treated with $1 \mu \mathrm{L}$ of $5 \mathrm{mM}$ Alexa Fluor azide to provide a final concentration of $0.5 \mathrm{mM}$. Click reaction proceeded for 2 hours prior to analysis on SDS-PAGE.

\section{Reduction of 1 labeled BSA with sodium dithionite}

$1 \mathrm{mM}$ BSA was diluted to $50 \mu \mathrm{M}$ in $0.1 \mathrm{M}$ PBS buffer $(\mathrm{pH} 7)$. To this sample was added 8 $\mu \mathrm{L}$ of $12.6 \mathrm{mM} 1(0.4 \mathrm{mM})$ in a total volume of $250 \mu \mathrm{L}$. The protein solution was left to react void of light overnight ( 16 hours). Next, the sample was split into two $125 \mu \mathrm{L}$ aliquots. The experimental sample was then treated with $6.25 \mu \mathrm{L}$ of $1 \mathrm{M}$ sodium dithionite to provide a final concentration of $50 \mathrm{mM}$. In the control sample, $6.25 \mu \mathrm{L}$ of buffer was added. The reduction reaction was incubated for 2 hours. Samples were then passed through a Size Exclusion Column with G-10 resin. Following buffer exchange, $10 \mu \mathrm{L}$ of each sample was treated with $1 \mu \mathrm{L}$ of $5 \mathrm{mM}$ Alexa Fluor azide to provide a final concentration of $0.5 \mathrm{mM}$. The click reaction proceeded for 2 hours prior to analysis on SDS-PAGE.

\section{Treatment of BSA with 1 in the presence of excess cysteine}

In a $1.6 \mathrm{~mL}$ Eppendorf, $1.25 \mu \mathrm{L}$ of $1 \mathrm{mM} \mathrm{BSA}$ was diluted into $0.1 \mathrm{M}$ PBS buffer $(\mathrm{pH} 7)$ to provide a final concentration of $25 \mu \mathrm{M}$ protein. Sample one, the positive control sample, was treated with $1.1 \mu \mathrm{L}$ of a $12.6 \mathrm{mM}$ stock of 1 dissolved in DMSO to provide a final concentration of $0.5 \mathrm{mM} 1$ in solution in a total volume of $50 \mu \mathrm{L}$. An analogous experimental sample was then made with $25 \mu \mathrm{M}$ BSA in $0.1 \mathrm{M}$ PBS $(\mathrm{pH} 7)$. Prior to addition of 1 , the sample was first treated with $2 \mu \mathrm{L}$ of a $0.5 \mathrm{M}$ stock of cysteine to provide a final cysteine concentration of $20 \mathrm{mM}$. The sample was subsequently treated with 0.5 $\mathrm{mM} 1$ and incubated overnight. $10 \mu \mathrm{L}$ of each sample was then treated with $0.5 \mu \mathrm{L}$ of 5 $\mathrm{mM}$ Alexa Fluor azide for 4 hours. Samples were compared on 12\% SDS-PAGE via scanning for fluorescence at $488 \mathrm{~nm}$.

\section{Treatment of DBCO-modified BSA with excess cysteine}

$25 \mu \mathrm{M}$ BSA was treated with $0.5 \mathrm{mM} 1$ overnight and then the sample was treated with $20 \mathrm{mM}$ resorcinol to quench potential diazonium reactivity. Next, the sample was split into two $50 \mu \mathrm{L}$ aliquots. The second aliquot was then treated with $20 \mathrm{mM}$ cysteine and let incubate for $\sim 16$ hours overnight. $10 \mu \mathrm{L}$ of each sample was then treated with $5 \mathrm{mM}$ Alexa Fluor azide for 4 hours. Samples were compared on 12\% SDS-PAGE via scanning for fluorescence at $488 \mathrm{~nm}$. 


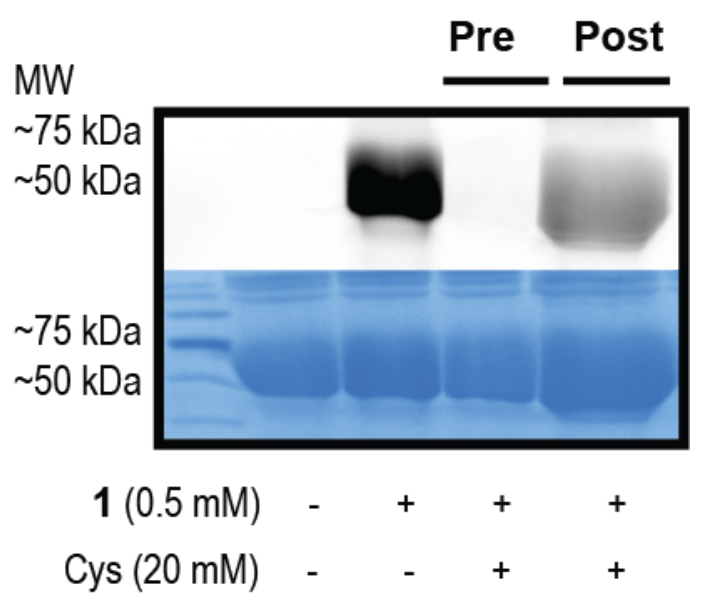

Figure S2. BSA treatment with $0.5 \mathrm{mM} 1$ was performed overnight (Lane 2). A second sample was treated first with $20 \mathrm{mM}$ cysteine prior to addition of 1 (Lane 3). The final sample took the BSA treated with 1 overnight and then further treated it with $20 \mathrm{mM}$ cysteine following an addition of resorcinol used to quench any remaining diazonium (Lane 4). Fluorescence was completely negated when cysteine was present during the initial diazonium conjugation. However, fluorescence remained when cysteine was introduced after conjugation indicating the cyclooctyne was mostly stable to thiol-yne reactivity.

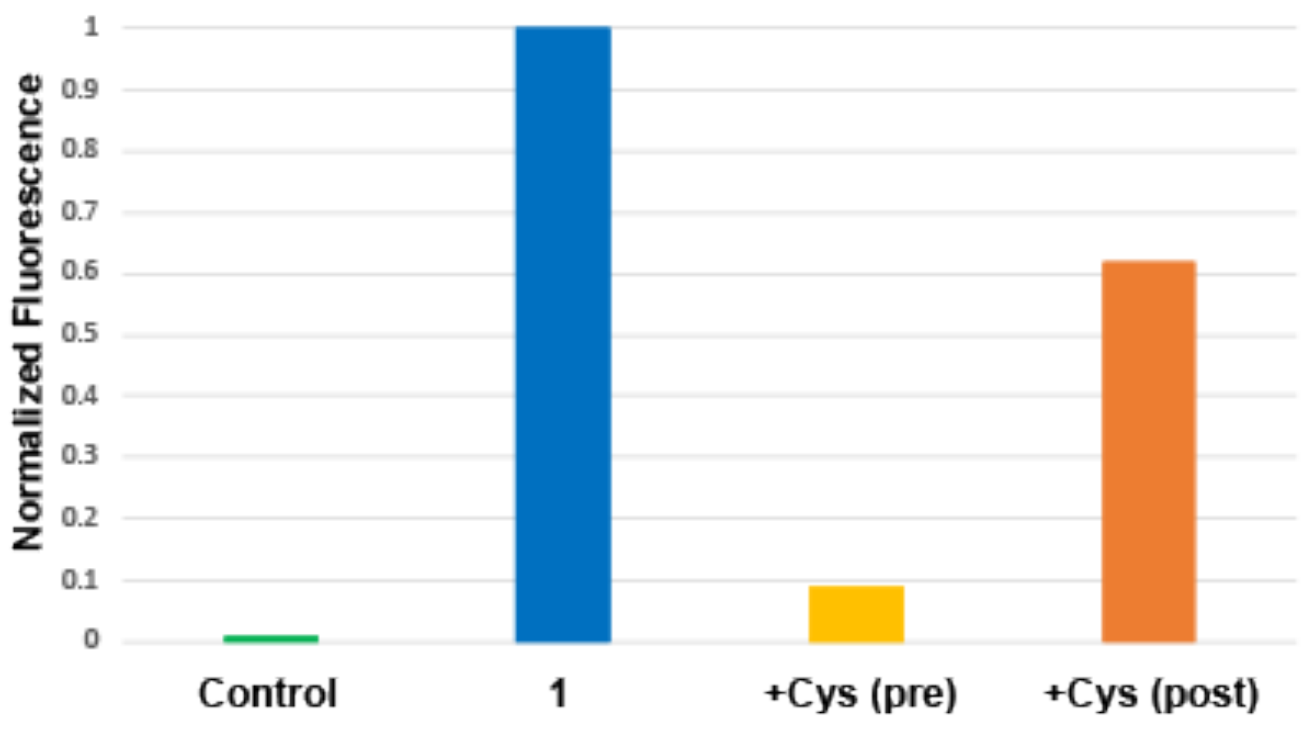

Figure S3. Quantification of normalized band fluorescence for control sample (green), BSA treated with $0.5 \mathrm{mM} 1$ (blue), BSA treated with $0.5 \mathrm{mM} 1$ in the presence of 20 $\mathrm{mM}$ cysteine (yellow), and BSA modified by 1 subsequently treated with $20 \mathrm{mM}$ cysteine (orange). 
Quantification of gel band fluorescence with ImageJ Software after cysteine treatment

Using ImageJ software, band intensities for both fluorescence and Coomassie scans were determined for each sample using the band integration tool. First, band fluorescence was normalized to the band with the highest fluorescence intensity amongst all samples by dividing all by its respective integration value. Next, we integrated the band intensity of the corresponding Coomassie stain. We then normalized the Coomassie band intensity to the highest band intensity providing a ratio between $0-1$. Lastly, each band fluorescence was divided by its respective Coomassie ration to normalize fluorescence intensity to the relative quantity of protein per band. This was done to accommodate for slight differences in protein concentrations between wells. Normalized fluorescent intensities were then plotted on a bar chart showing relative fluorescence on a scale from 0 to 1 (SF3).

\section{SDS-PAGE analysis of MSP1D1T2(-) labeling with 1 and AlexaFluor azide}

For initial determination of labeling of MSP by 1 , we chose to treat MSP1 with 1 and then subsequently treated the sample with Alexa Fluor azide $(488 \mathrm{~nm})$ in order to be analyzed for fluorescence on SDS-PAGE. $10 \mu \mathrm{L}$ of a $25 \mu \mathrm{M}$ solution of MSP previously treated with $0.5 \mathrm{mM}$ of 1 was subsequently treated with $0.25 \mathrm{mM}$ of the fluorescent azide via addition of $1.25 \mu \mathrm{L}$ of a $5 \mathrm{mM}$ stock of Alexa Fluor azide in DMSO. This sample was compared to an analogous protein sample containing equal concentration $(25 \mu \mathrm{M})$ of MSP and treated with $0.25 \mathrm{mM}$ azide, but not previously treated with 1 . Samples were incubated at RT for 1 hour prior to loading on 12\% SDS-PAGE gel and analyzed using $488 \mathrm{~nm}$ laser line. 


\section{Labeling of MSP1D1T2(-) with 1 and PEG - Biotin Azide}

An initial stock of $150 \mu \mathrm{M}$ MSP was provided to us following expression and purification previously described. ${ }^{1}$ The stock was used to make 2 samples consisting of MSP in 0.1 $\mathrm{M}$ PBS buffer $\mathrm{pH}$ 7. For the non-modified control, $16.7 \mu \mathrm{L}$ of the protein was added directly to $83.3 \mu \mathrm{L}$ of PBS buffer $\mathrm{pH} 7$ and incubated ( $25 \mu \mathrm{M}$ protein). For the TBD treated sample, the volume was increased to $500 \mu \mathrm{L}$ to allow for aliquots. $83.5 \mu \mathrm{L}$ of protein was added to $396.5 \mu \mathrm{L}$ of PBS buffer $\mathrm{pH} 7$ to provide a final protein concentration of $25 \mu \mathrm{M}$ protein. The sample was then treated with $20 \mu \mathrm{L}$ of $12.6 \mathrm{mM} 1$ to provide a concentration of 0.5 $\mathrm{mM}$ of 1 . The samples were then incubated overnight ( 14 hrs). Following prolonged incubation, the 1 treated sample was split into two aliquots of $200 \mu \mathrm{L}$. Both aliquots were treated with $100 \mathrm{mM}$ resorcinol prior to further additions in order to quench and possible remaining diazonium activity. The first aliquot was not treated further. The second aliquot was then treated with $\mathrm{PEG}_{2}$ - Biotin azide. First, a $20 \mathrm{mM}$ stock of the biotin azide was made in DMSO by dissolving $8 \mathrm{mg}$ in $1 \mathrm{~mL}$ of DMSO. Next, $5 \mu \mathrm{L}$ of the stock was added to the $200 \mu \mathrm{L} 1$ treated sample to provide a final concentration of $0.49 \mathrm{mM}$ ( 1 equivalent) of azido biotin relative to 1 . The sample was further incubated at room temperature for 4 hours before being placed in the $-20^{\circ} \mathrm{C}$ freezer until the sample could be prepped for Native MS. 


\section{MSP1D1T2(-) sample analysis by Native Mass Spectrometry}

Each sample was buffer exchanged twice into $0.2 \mathrm{M}$ ammonium acetate $(\mathrm{pH}$ 6.8) using a Micro Bio-spin P-6 column (BioRad). The final concentration of each sample prior to analysis was $\sim 65 \mu \mathrm{M}$. Native mass spectrometry (MS) was performed using the QExactive HF quadrupole-Orbitrap mass spectrometer with Ultra-High Mass Range modifications (Thermo Fisher Scientific). Native mass spectrometry was performed in positive-ion mode using borosilicate nano-electrospray ionization needles pulled using a P-1000 micropipette puller (Sutter Instrument, Novato, CA). Instrumental parameters applied include $1.1 \mathrm{kV}$ spray voltage, $50 \mathrm{~V}$ source voltage, and $50 \mathrm{~V}$ collisional voltage. The instrument had a trapping gas pressure set to 3 . The scan range for all samples was $1,500-15,000 \mathrm{~m} / \mathrm{z}$, and the instrumental resolution was set to 15,000 . Data was analyzed with UniDec. ${ }^{7}$

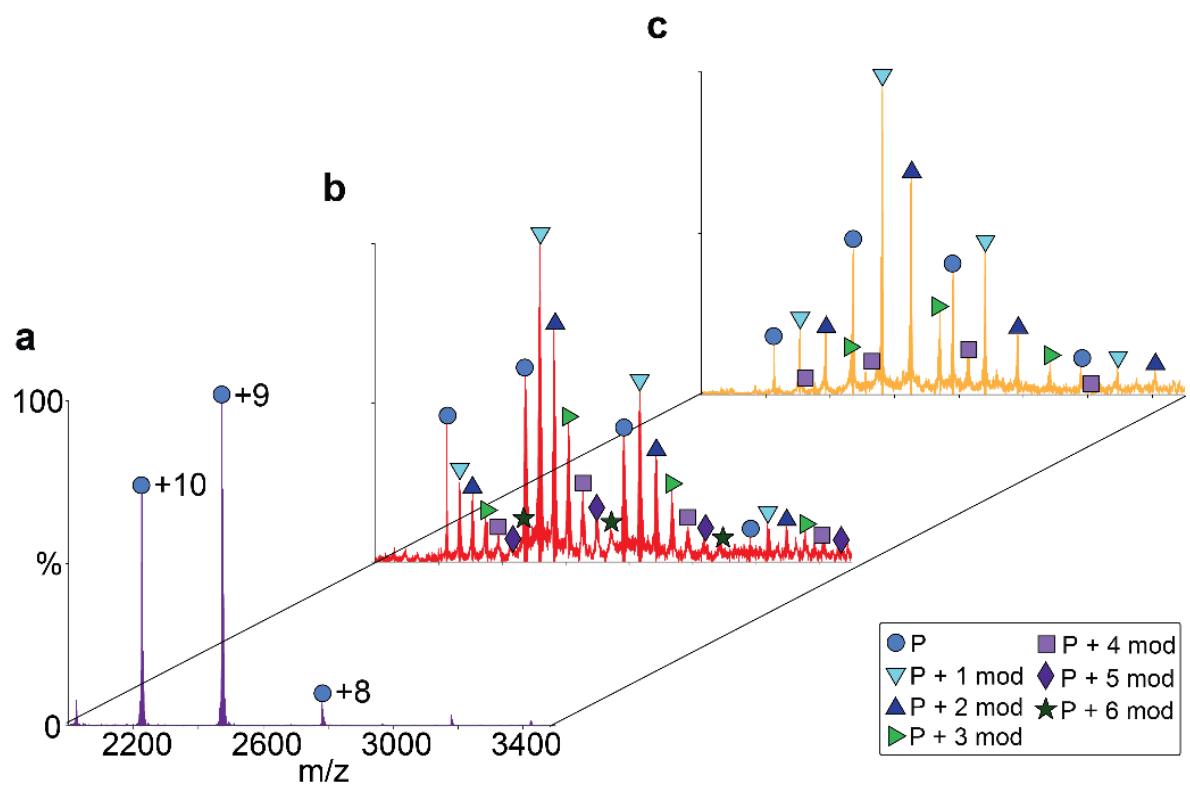

Figure S4. $\mathrm{m} / \mathrm{z}$ data collected for comparison of MSP1D1T2(-) (MSP) before and after modification with 1 and subsequent copper-free click functionalization (a) Native MS $\mathrm{m} / \mathrm{z}$ data for MSP control (purple). (b) Native MS m/z data for MSP treated with $0.5 \mathrm{mM} 1$ (red). (c) Native MS $\mathrm{m} / \mathrm{z}$ data for MSP treated with $0.5 \mathrm{mM} 1$ followed with treatment by $0.5 \mathrm{mM} \mathrm{PEG}_{2}$-biotin azide (orange). 


\section{Extraction of Hen Egg proteins from commercial chicken eggs}

6 fresh commercial chicken eggs were broken, and the contents were collected in a Tupperware ${ }^{\circledR}$ container. The egg contents were then stirred thoroughly with a metal spatula. The egg protein solution was then diluted with $50 \mathrm{~mL}$ of lysis buffer $(50 \mathrm{~mL}$ Tris $\mathrm{pH} 7.4,2 \mathrm{mM}$ EDTA, $2 \mathrm{mM}$ EGTA, 1\% NP-40) and thoroughly stirred prior to transfer to $50 \mathrm{~mL}$ conical tubes. After capping the tubes, they were shaken further. Samples were then centrifuged at $4,000 \mathrm{rpm}$ for 20 minutes at $4{ }^{\circ} \mathrm{C}$ for clarification. Samples were then diluted by transferring $10 \mathrm{~mL}$ of lysis buffer extract into $40 \mathrm{~mL}$ of $0.1 \mathrm{M} \mathrm{PBS}(\mathrm{pH} \mathrm{6.5)}$. Samples were then centrifuged a second time $\left(4,000 \mathrm{rpm}, 20\right.$ minutes, $\left.4{ }^{\circ} \mathrm{C}\right)$. The remaining contents were removed to fresh conical tubes and stored indefinitely at $4{ }^{\circ} \mathrm{C}$.

\section{Treatment of Hen Egg protein extract with 1}

$234 \mu \mathrm{L}$ of Hen Egg protein extract $(\mathrm{pH} 6.5)$ was treated with $16 \mu \mathrm{L}$ of $12.6 \mathrm{mM} 1$ to provide a final treatment of $0.8 \mathrm{mM}$. The control sample was treated with $16 \mu \mathrm{L}$ of DMSO in place of 1. Samples were incubated overnight ( 16 hours) void of light. $10 \mu \mathrm{L}$ of each sample was treated with $2 \mu \mathrm{L}$ of $5 \mathrm{mM}$ Alexa Fluor azide to provide a final concentration of $1 \mathrm{mM}$. The click reaction proceeded for 2 hours prior to analysis on SDS-PAGE.

\section{Test for bioorthogonal capability of BSA modified by 1}

$25 \mu \mathrm{L}$ of $1 \mathrm{mM}$ BSA was transferred to two $1.6 \mathrm{~mL}$ Eppendorf tubes. To each was added $209 \mu \mathrm{L}$ of 0.1 M PBS buffer (pH 7). To the control sample, $16 \mu \mathrm{L}$ of DMSO was added. For the experimental sample, $16 \mu \mathrm{L}$ of $12.6 \mathrm{mM} 1$ was added to provide a total volume of $250 \mu \mathrm{L}$ and a final protein concentration of $100 \mu \mathrm{M}$ and a final TBD concentration of 0.8 $\mathrm{mM}$ (8 equiv). Samples were incubated overnight void of light. $2.5 \mu \mathrm{L}$ of each sample was then transferred to respective Eppendorf tubes. To this first set was added $7.1 \mu \mathrm{L}$ of 0.1 M PBS buffer ( $\mathrm{pH} 7$ ), as well as $0.4 \mu \mathrm{L}$ of $5 \mathrm{mM}$ Alexa Fluor azide to provide a final protein concentration of $25 \mu \mathrm{M}$, and a final fluorophore concentration of $0.2 \mathrm{mM}(\sim 1: 1$ equiv 1 : azide). Samples were then incubated for 6 hours void of light at room temperature. In a second set of samples, $2.5 \mu \mathrm{L}$ of the control and the 1 treated BSA was transferred to Eppendorf tubes containing 7.1 $\mu \mathrm{L}$ of Hen Egg protein extract. These samples were further treated with $0.4 \mu \mathrm{L}$ of $5 \mathrm{mM}$ Alexa Fluor azide to provide a final protein concentration of $25 \mu \mathrm{M}$, and a final fluorophore concentration of $0.2 \mathrm{mM}(\sim 1: 1$ equiv 1 : azide). All samples were then loaded on SDS-PAGE and analyzed. 


\section{Absorbance Spectra}

TBD-cyclooctyne (1)

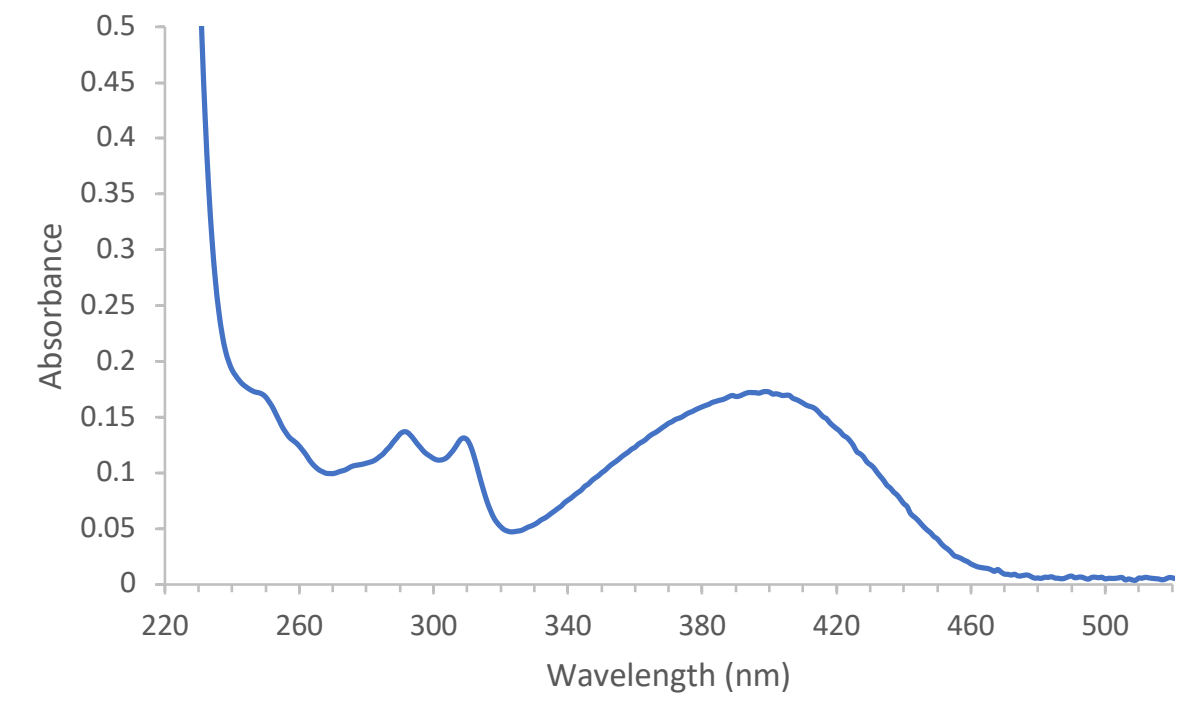

Figure S5. A $6.3 \mu \mathrm{M}$ stock solution of 1 in DMSO was diluted into $2 \mathrm{~mL}$ of $\mathrm{MeOH}$ and scanned for absorbance from $200 \mathrm{~nm}$ to $550 \mathrm{~nm}$. 


\section{References}

(1) Reid, D.J.; Keener, J.E.; Wheeler, A.P.; Zambrano, D.E.; Diesing, J.M.; Reinhardt-Szyba, M.; Makarov, A.; Marty, M.T. Engineering Nanodisc Scaffold Proteins for Native Mass Spectrometry. Anal. Chem. 2017, 89 (21), 11189_ 11192.

(2) Jensen, S. M.; Kimani, F. W.; Jewett, J. C. Light-Activated Triazabutadienes for the Modification of a Viral Surface. ChemBioChem 2016, 17 (23), 2216-2219.

(3) Levens, A.; An, F.; Breugst, M.; Mayr, H.; Lupton, D. W. Influence of the NSubstituents on the Nucleophilicity and Lewis Basicity of N-Heterocyclic Carbenes. Org. Lett. 2016, 18 (15), 3566-3569.

(4) Naranjo, T.; Lemishko, K. M.; de Lorenzo, S.; Somoza, Á.; Ritort, F.; Pérez, E. M.; Ibarra, B. Dynamics of Individual Molecular Shuttles under Mechanical Force. Nat. Commun. 2018, 9 (1), 1-7.

(5) Jiang, Y. L.; Zhu, Y.; Moore, A. B.; Miller, K.; Broome, A. M. Biotinylated Bioluminescent Probe for Long Lasting Targeted in Vivo Imaging of Xenografted Brain Tumors in Mice. ACS Chem. Neurosci. 2018, 9 (1), 100-106.

(6) Farzan, V. M.; Ulashchik, E. A.; Martynenko-Makaev, Y. V.; Kvach, M. V.; Aparin, I. O.; Brylev, V. A.; Prikazchikova, T. A.; Maklakova, S. Y.; Majouga, A. G.; Ustinov, A. V. et al. Automated Solid-Phase Click Synthesis of Oligonucleotide Conjugates: From Small Molecules to Diverse N-Acetylgalactosamine Clusters. Bioconjug. Chem. 2017, 28 (10), 2599-2607.

(7) Marty, M. T.; Baldwin, A. J.; Marklund, E. G.; Hochberg, G. K. A.; Benesch, J. L. P.; Robinson, C. V. Bayesian Deconvolution of Mass and Ion Mobility Spectra: From Binary Interactions to Polydisperse Ensembles. Anal. Chem. 2015, 87 (8), 4370-4376.

\section{NMR Spectra}

NMR spectra were taken on a Bruker AVIII-400 NMR Spectrometer for ${ }^{1} \mathrm{H}$ and ${ }^{13} \mathrm{C}$ NMR and referenced with residual solvent peaks at $7.26 \mathrm{ppm}$ and $77.0 \mathrm{ppm}$ for $\mathrm{CDCl}_{3}, 2.50$ and $39.5 \mathrm{ppm}$ for DMSO- $\mathrm{d}_{6}$ unless specified. Only the NMR of the final product (1) was obtained using Bruker AVIII-500 NMR. 


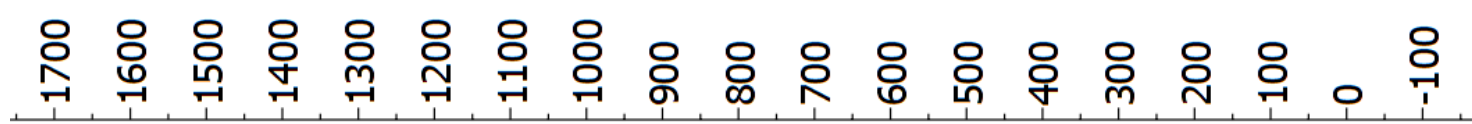

OSWO OS'Z-

\section{$\mathrm{OOH} \varepsilon \varepsilon^{*} \varepsilon-$}
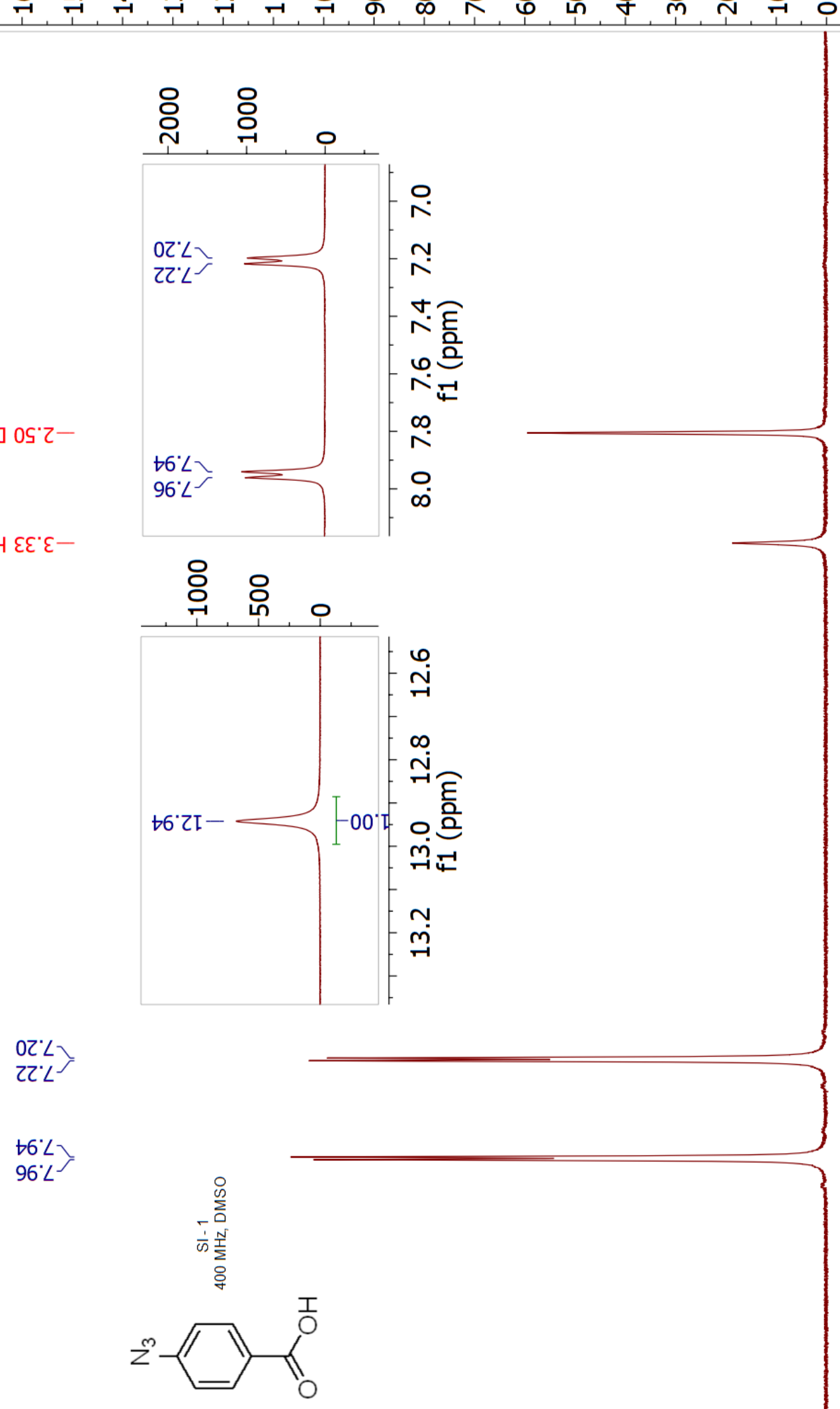

$\left[\begin{array}{l}\text { nீ } \\ 0 \\ 0 \\ 0 \\ 0 \\ 0\end{array}\right.$ 


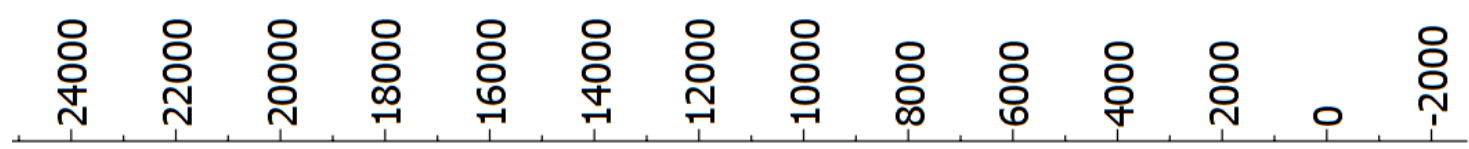

OSWO $88^{\circ} 8 \varepsilon$

OSWO $\left.80^{\circ} 6 \varepsilon\right]$

OSWO $6 Z^{\circ} 6 \varepsilon$ ]

OSWO OS' $6 \varepsilon$

OSWO I $\angle{ }^{\prime} 6 \varepsilon^{\top}$

OSWO $26^{\circ} 6 \varepsilon$

OSWO EI"Ot

SI6II-

$\angle Z Z^{\prime} L Z I-$

6I'IEI-

乙6. $ย \vdash โ-$

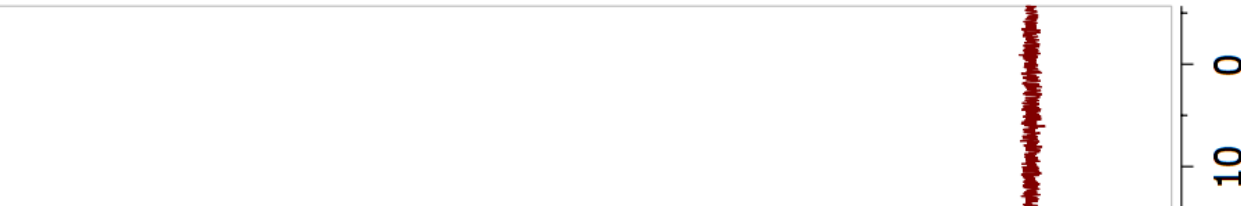

윽

음

음

우

요

8

옷

-

ชำ

윰ㄷㄴ

음

유

임

옴

음

움

عS'99I-

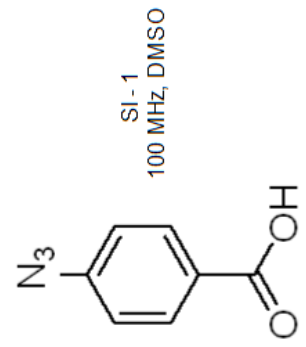

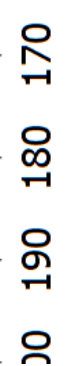




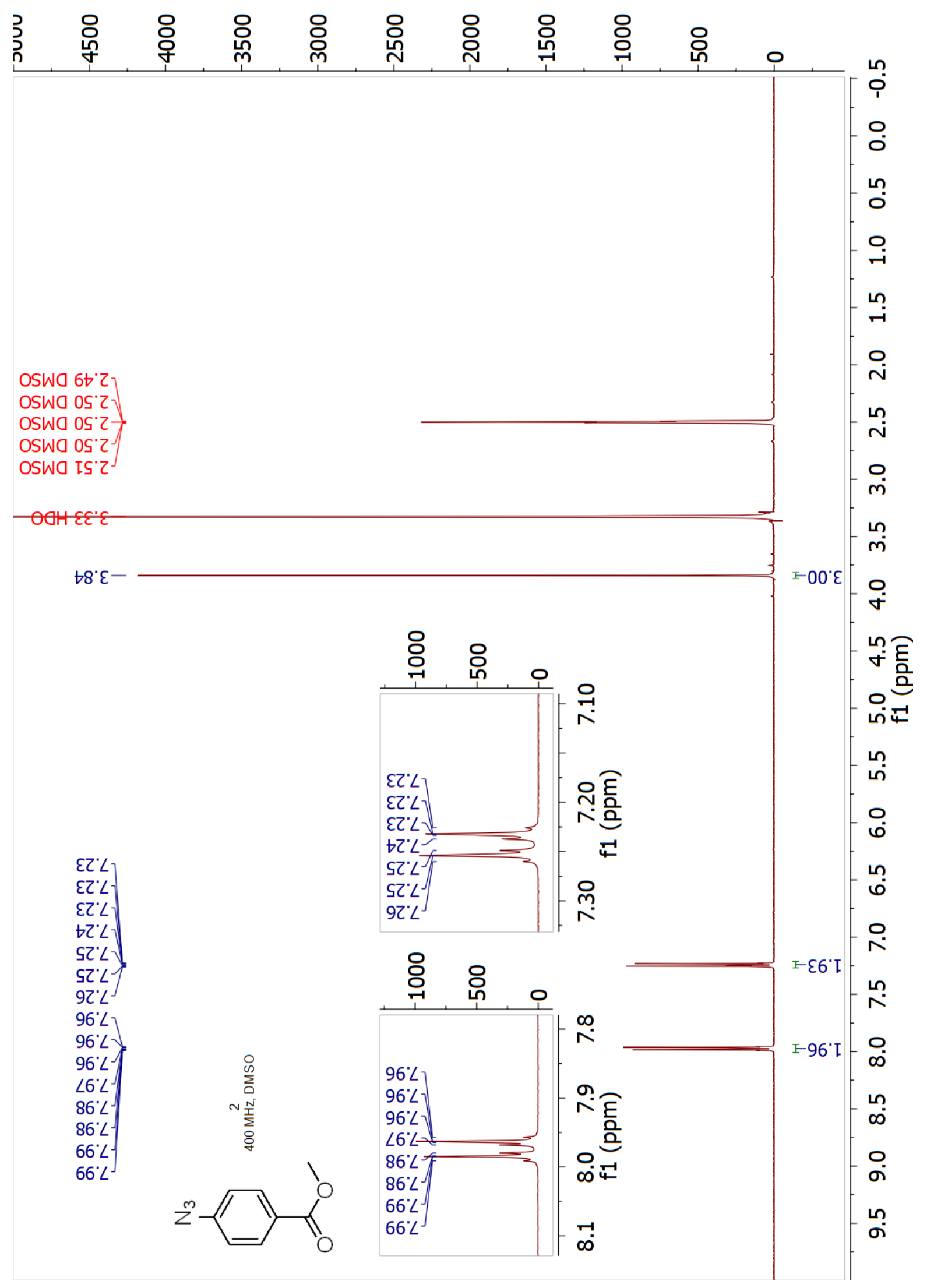




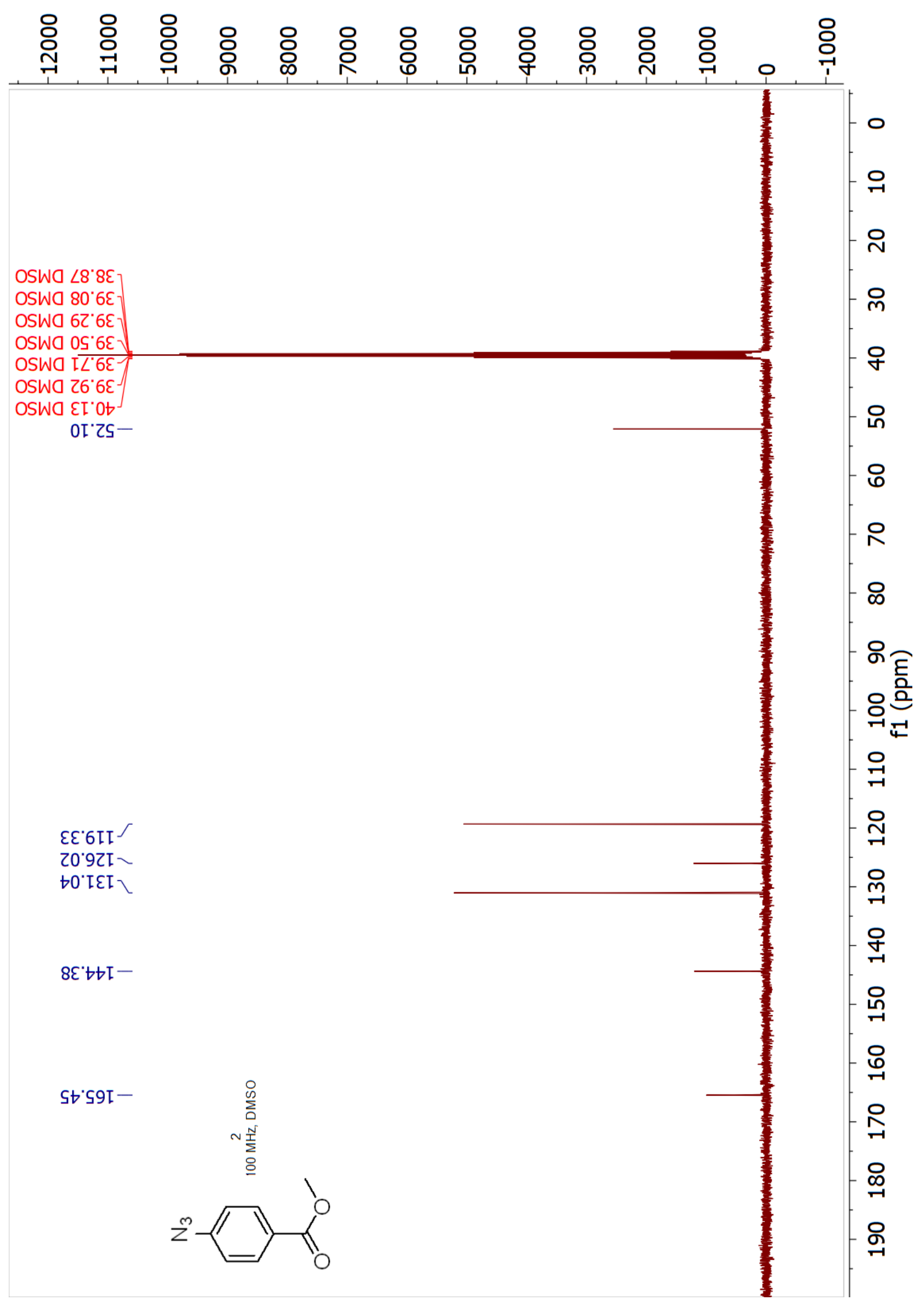




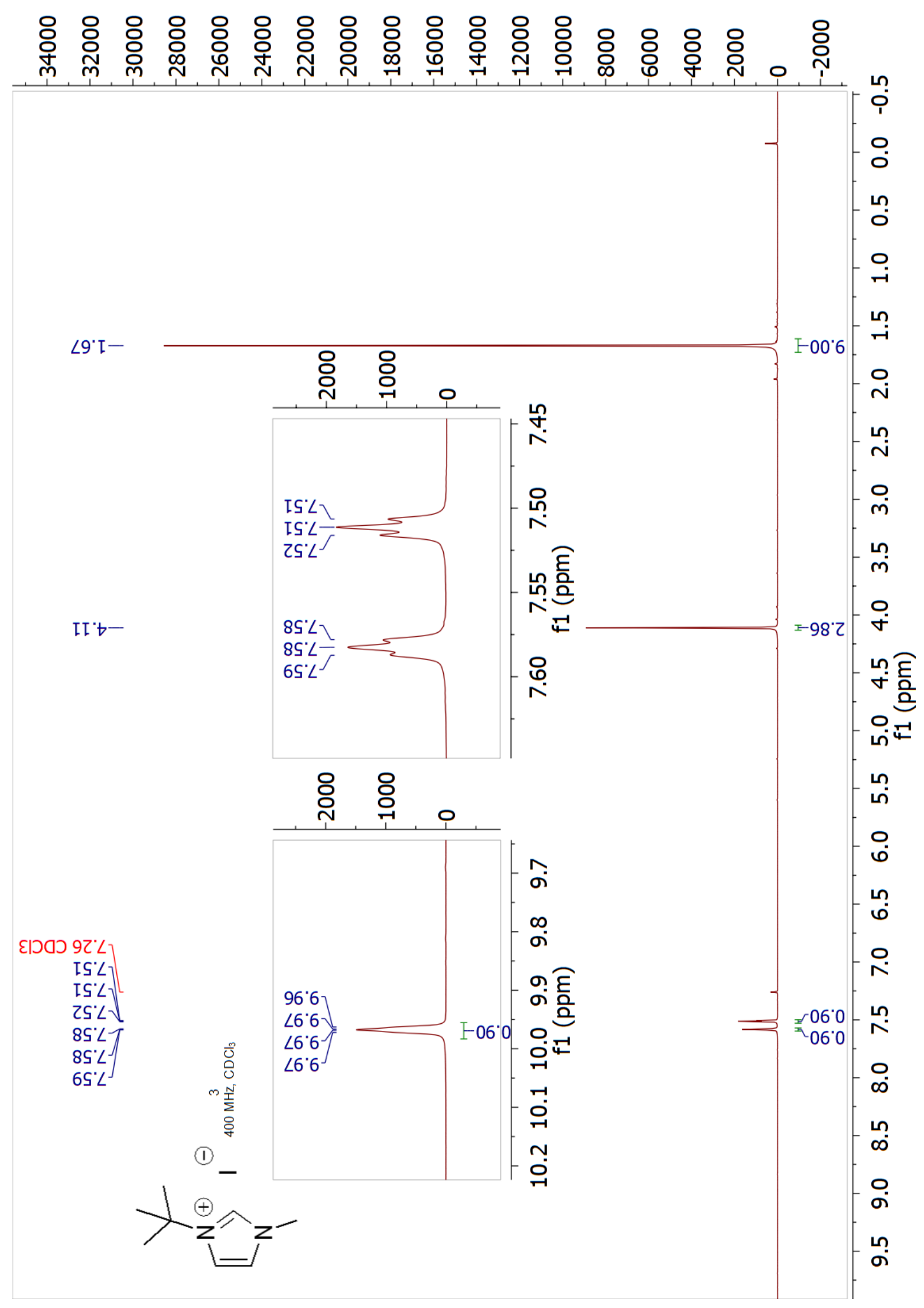




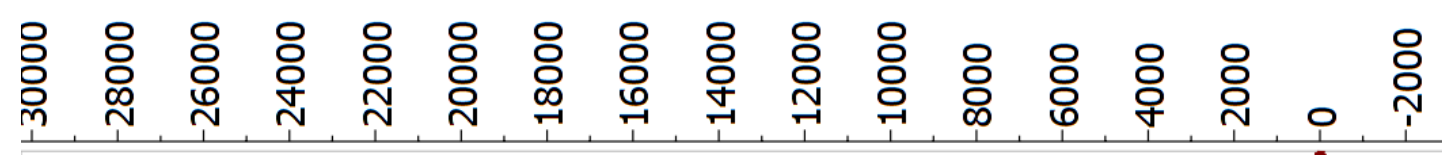

6ع.09-

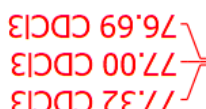

$8 t^{\circ} 6 I-$

ธ8'ยZI-

OZ'SEI-
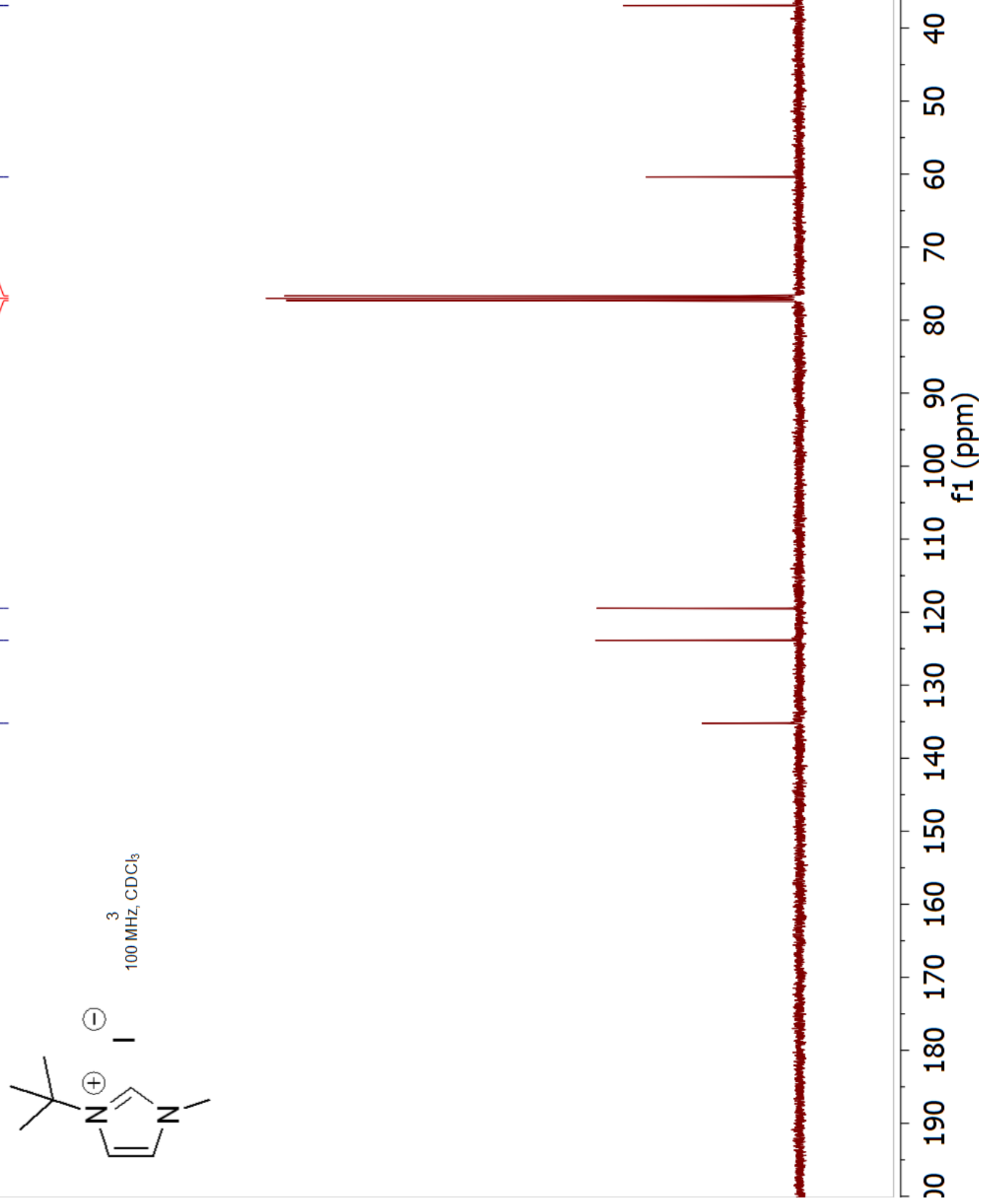


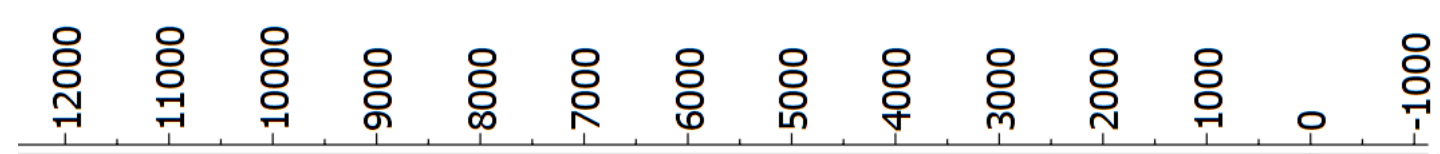

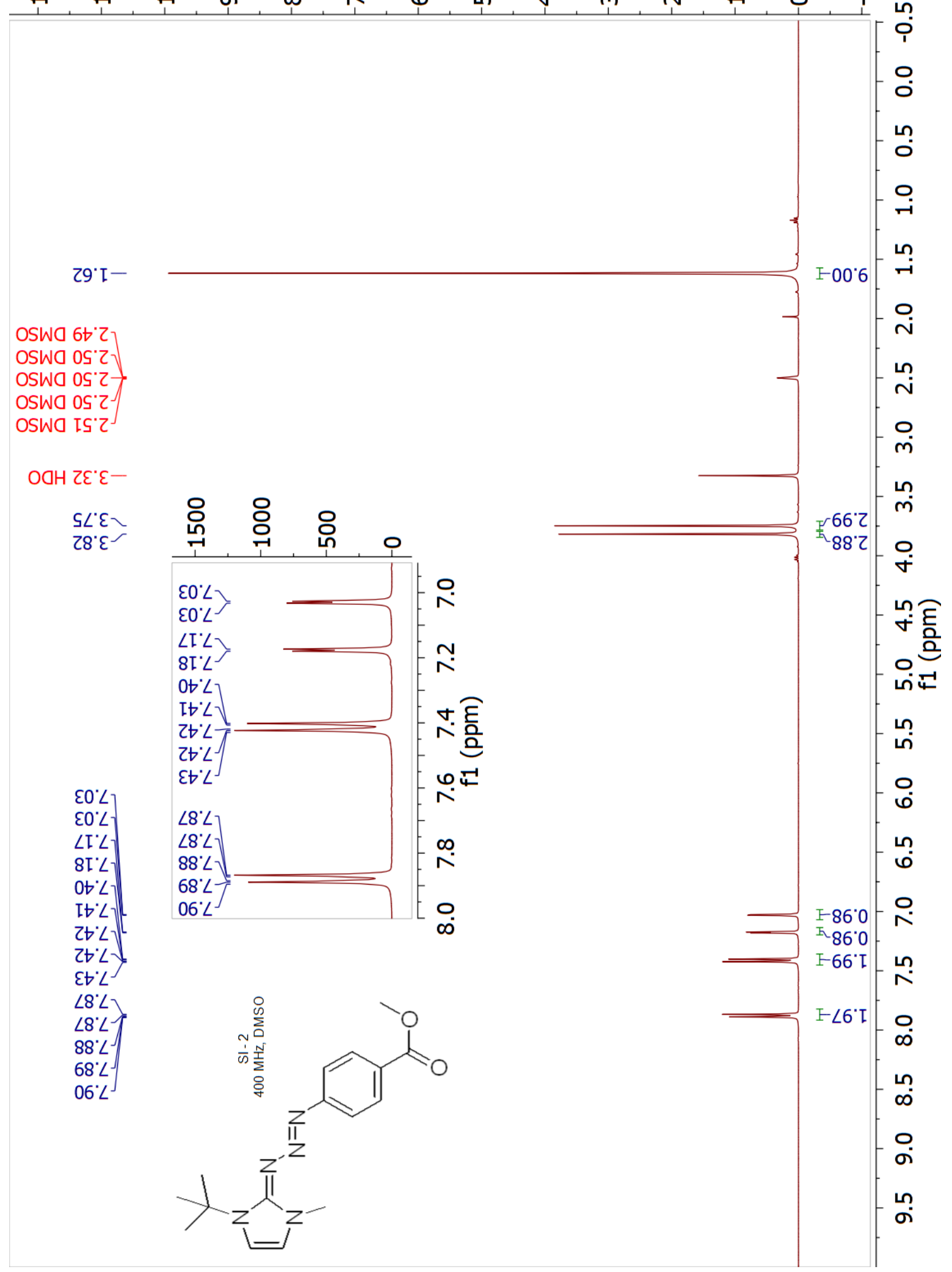




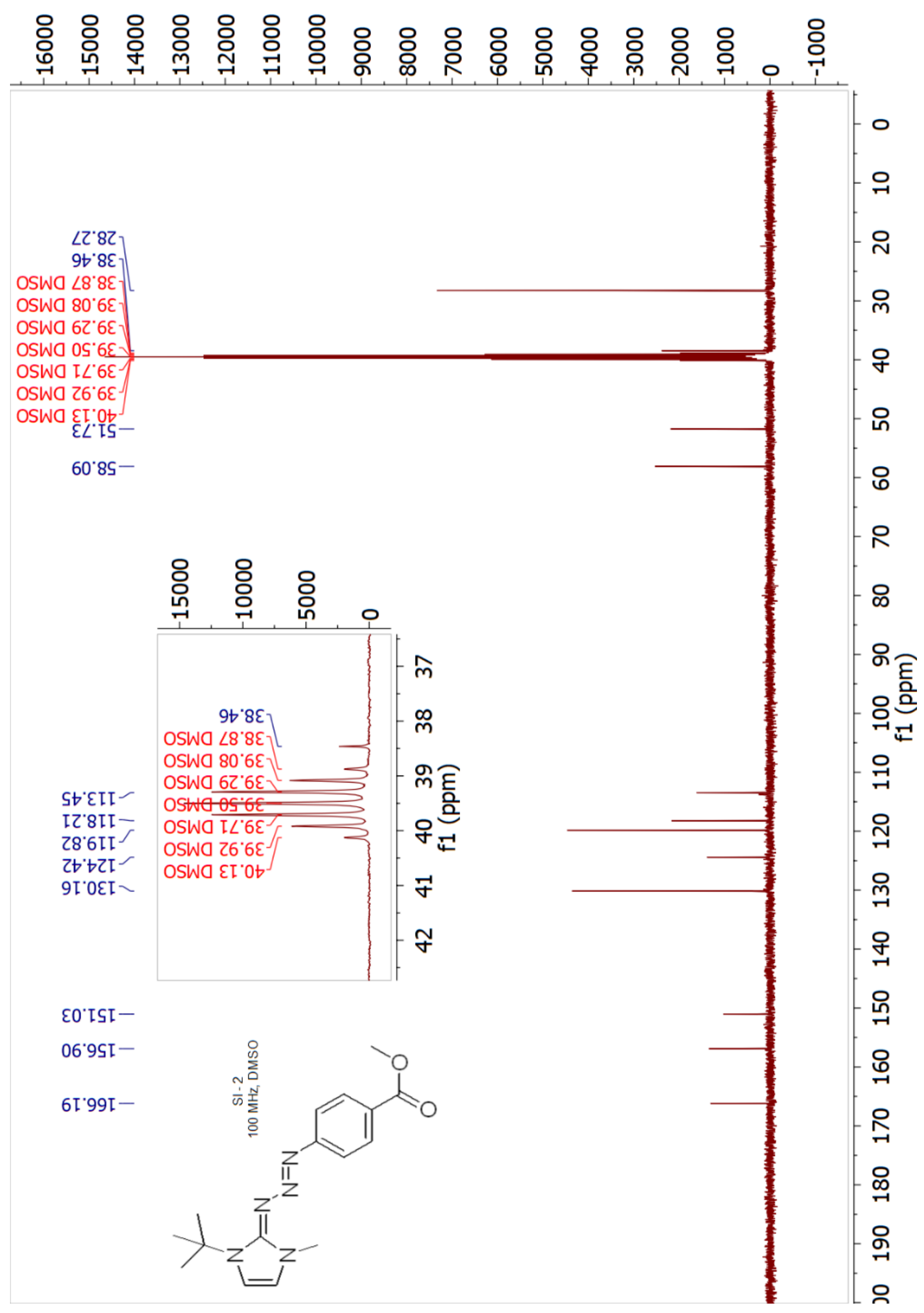




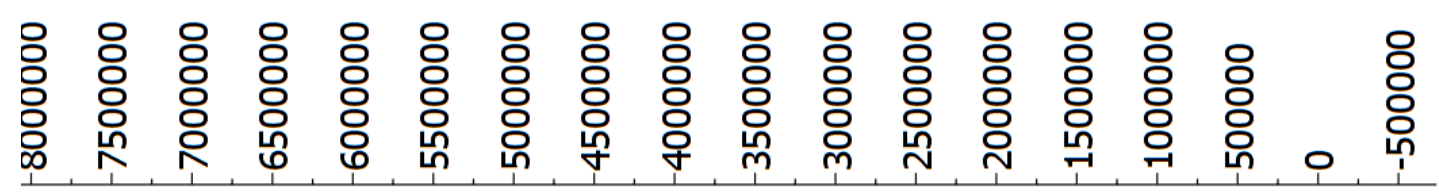

OSWO OS'Z-
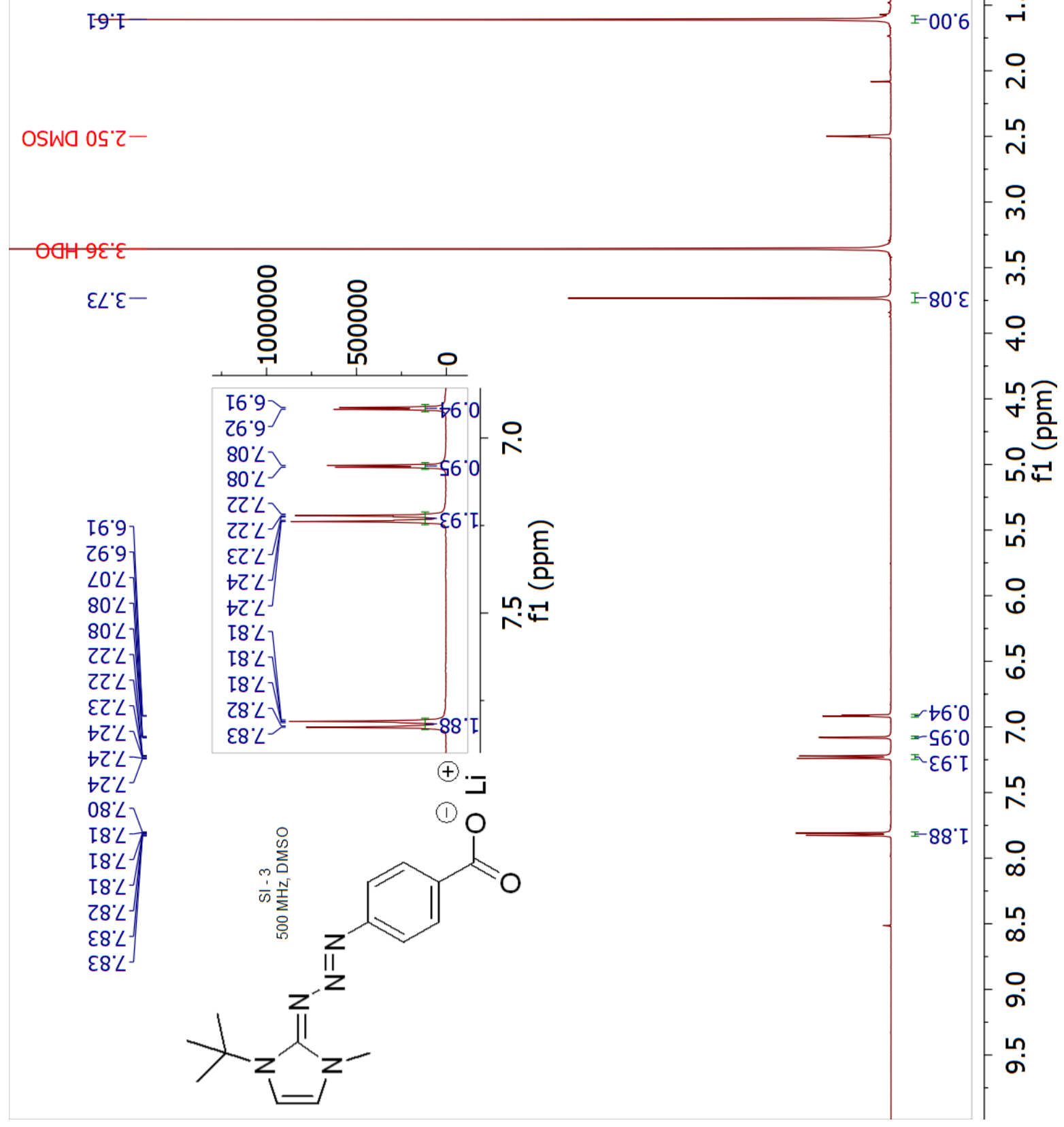


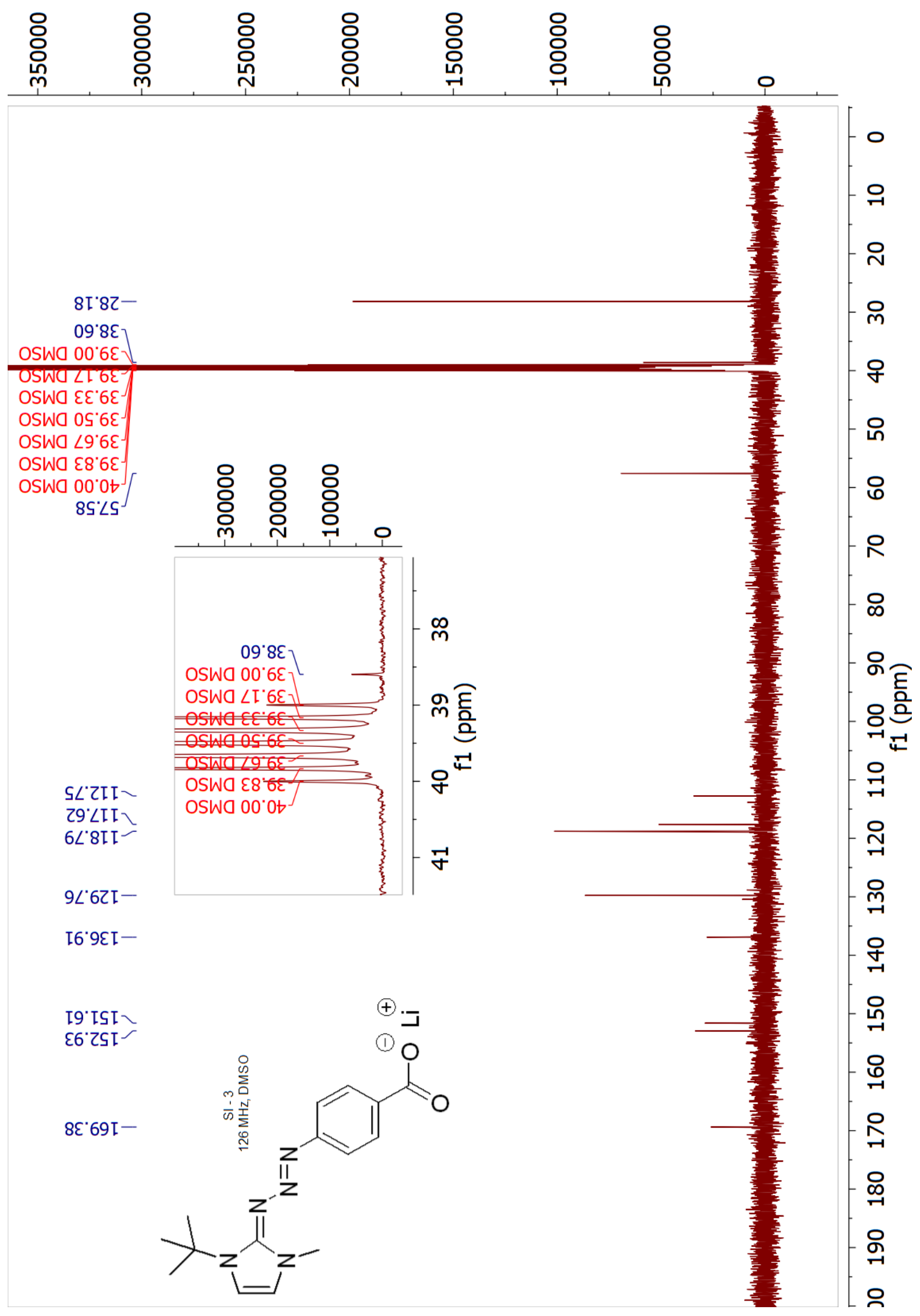




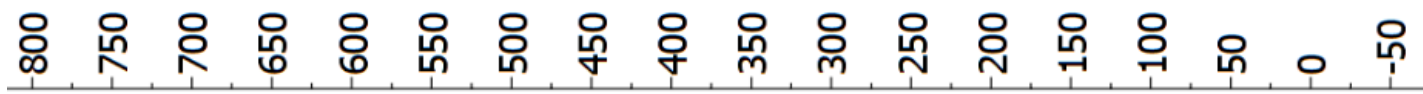

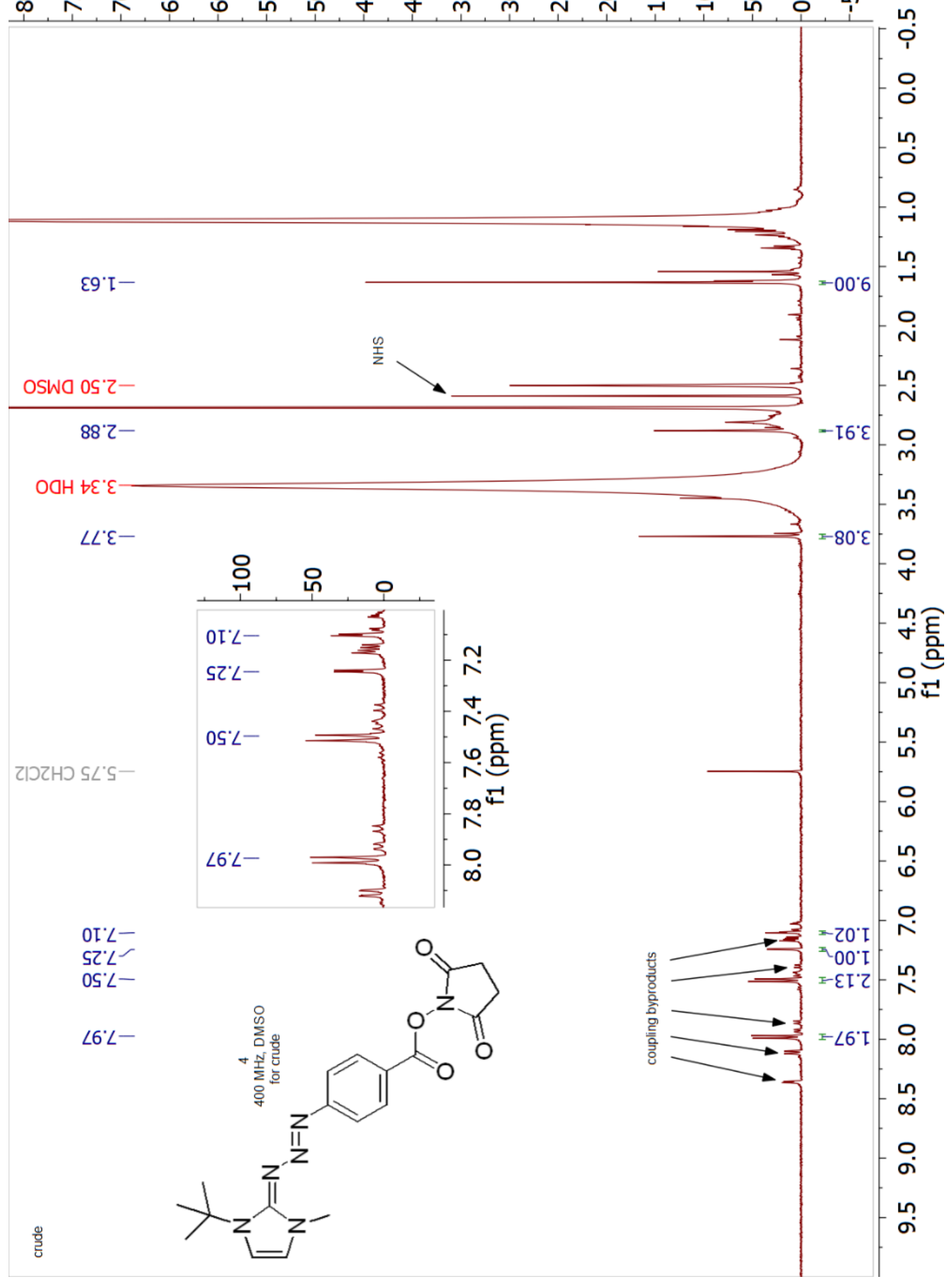




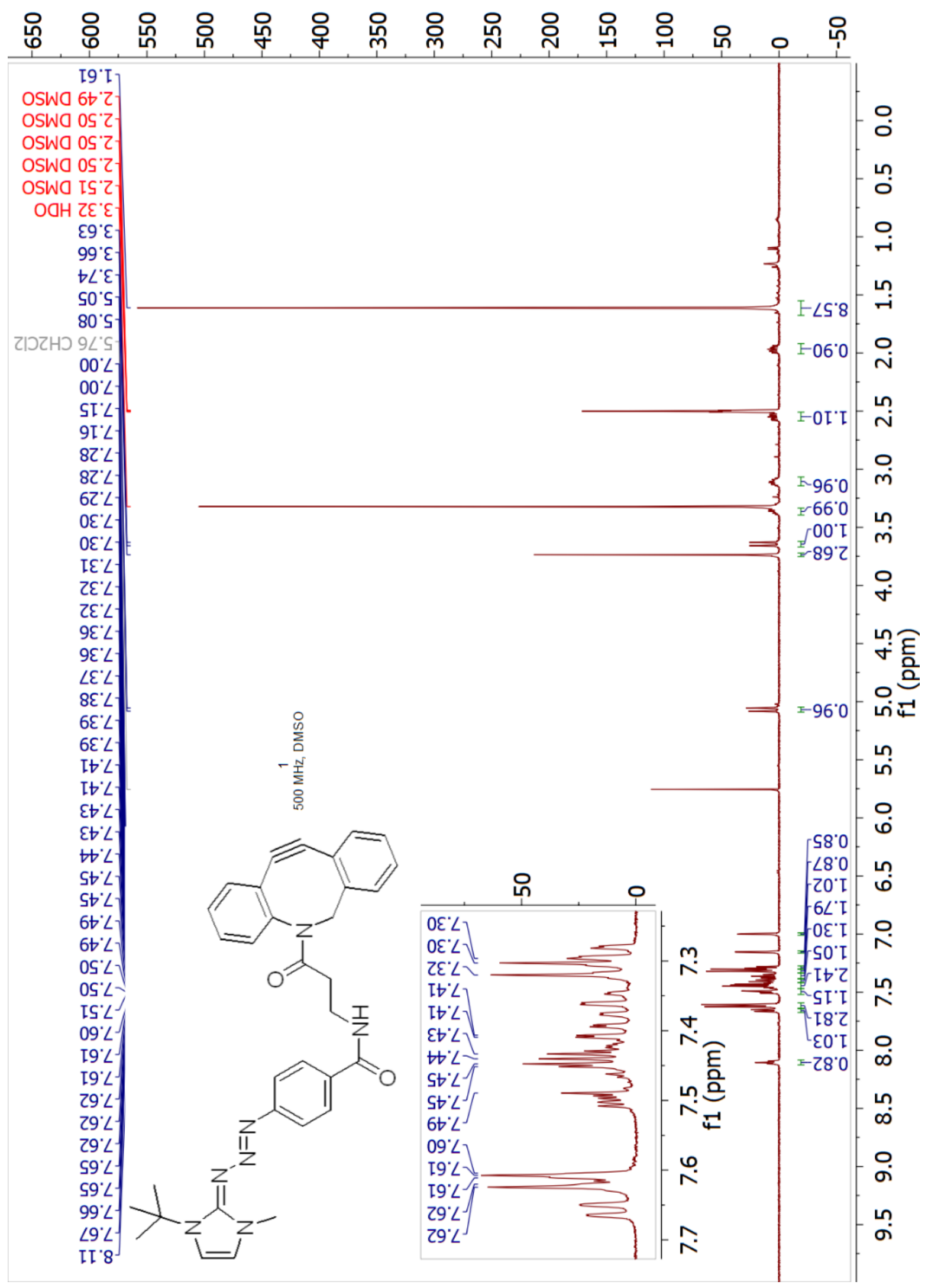




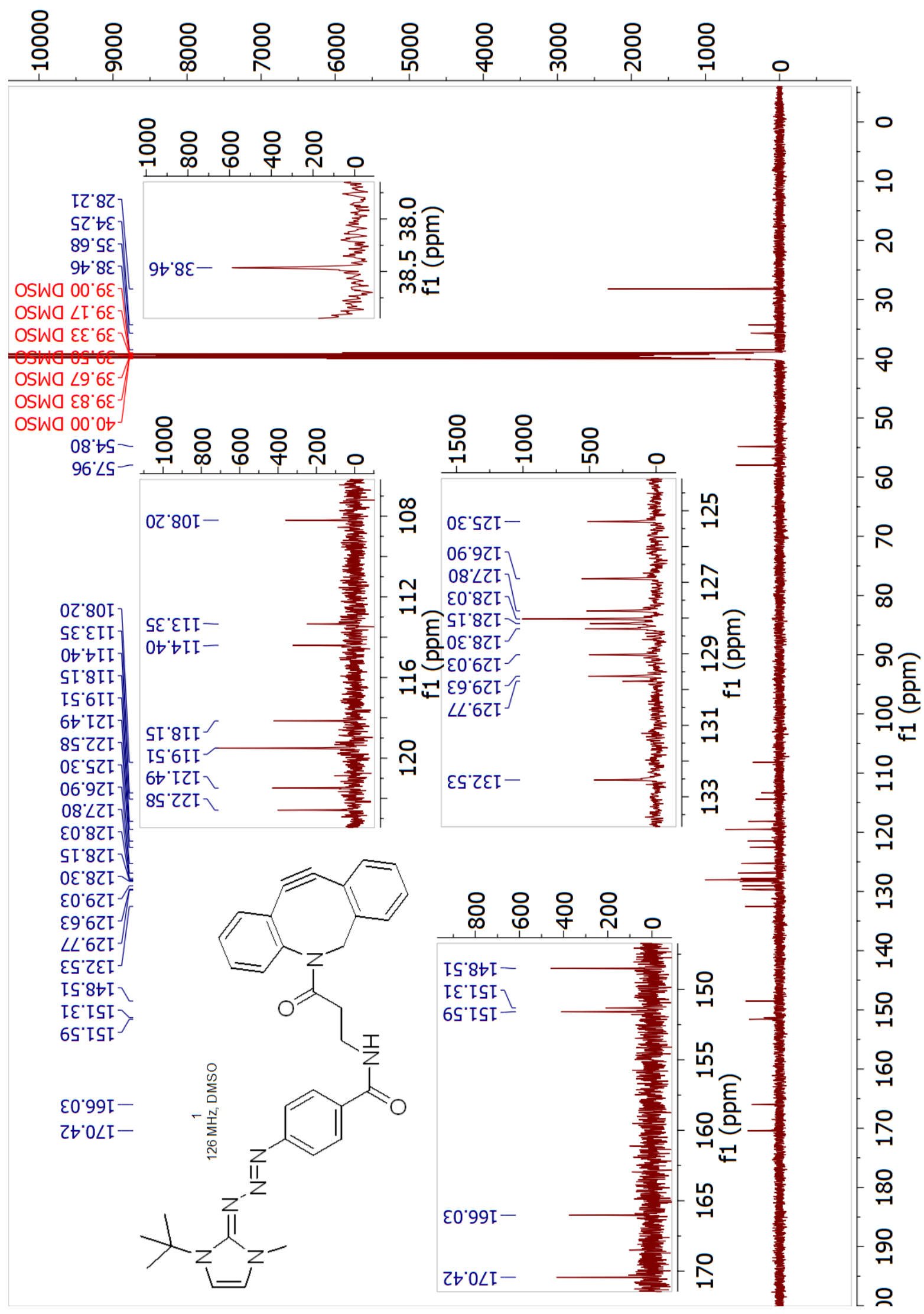




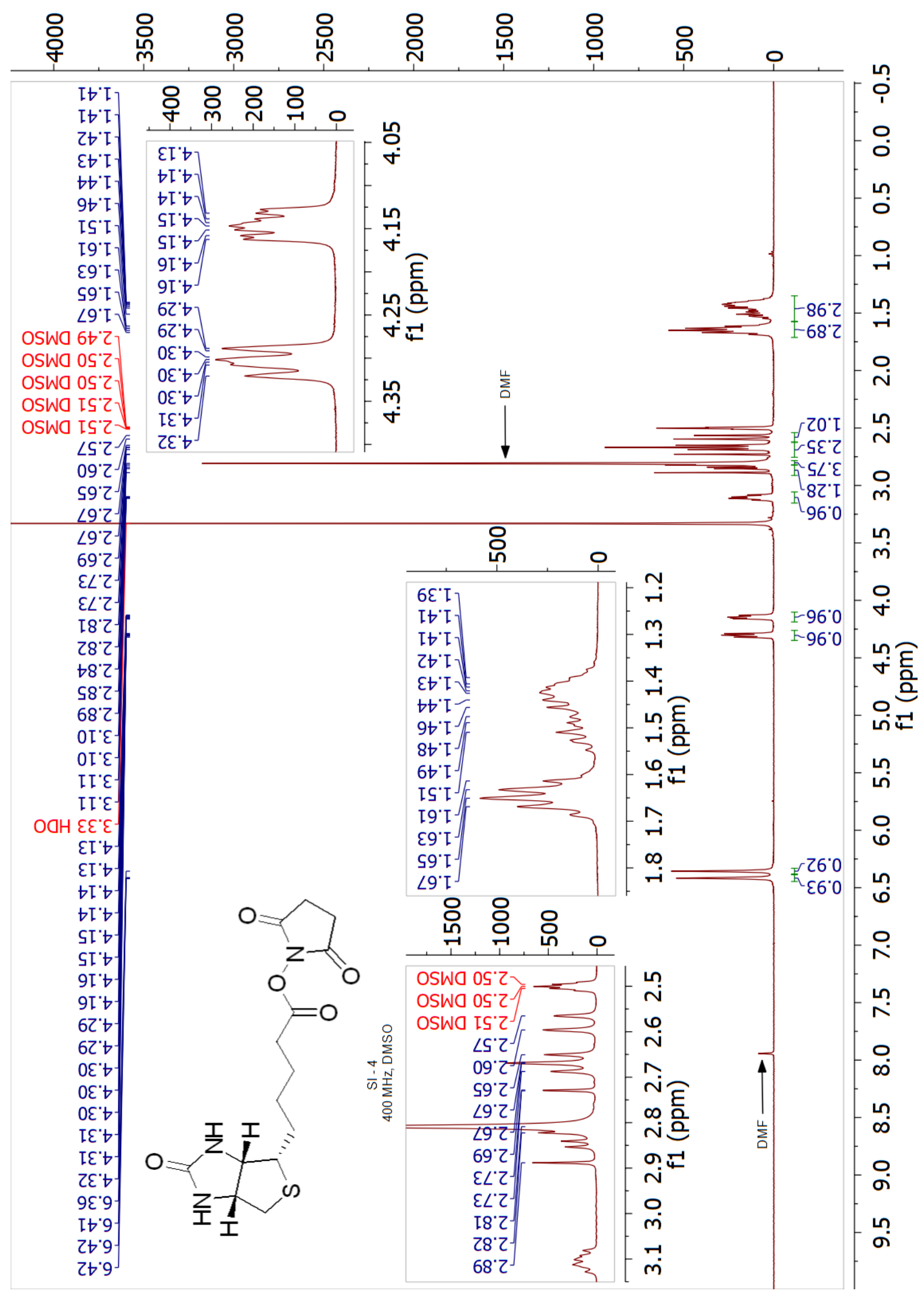



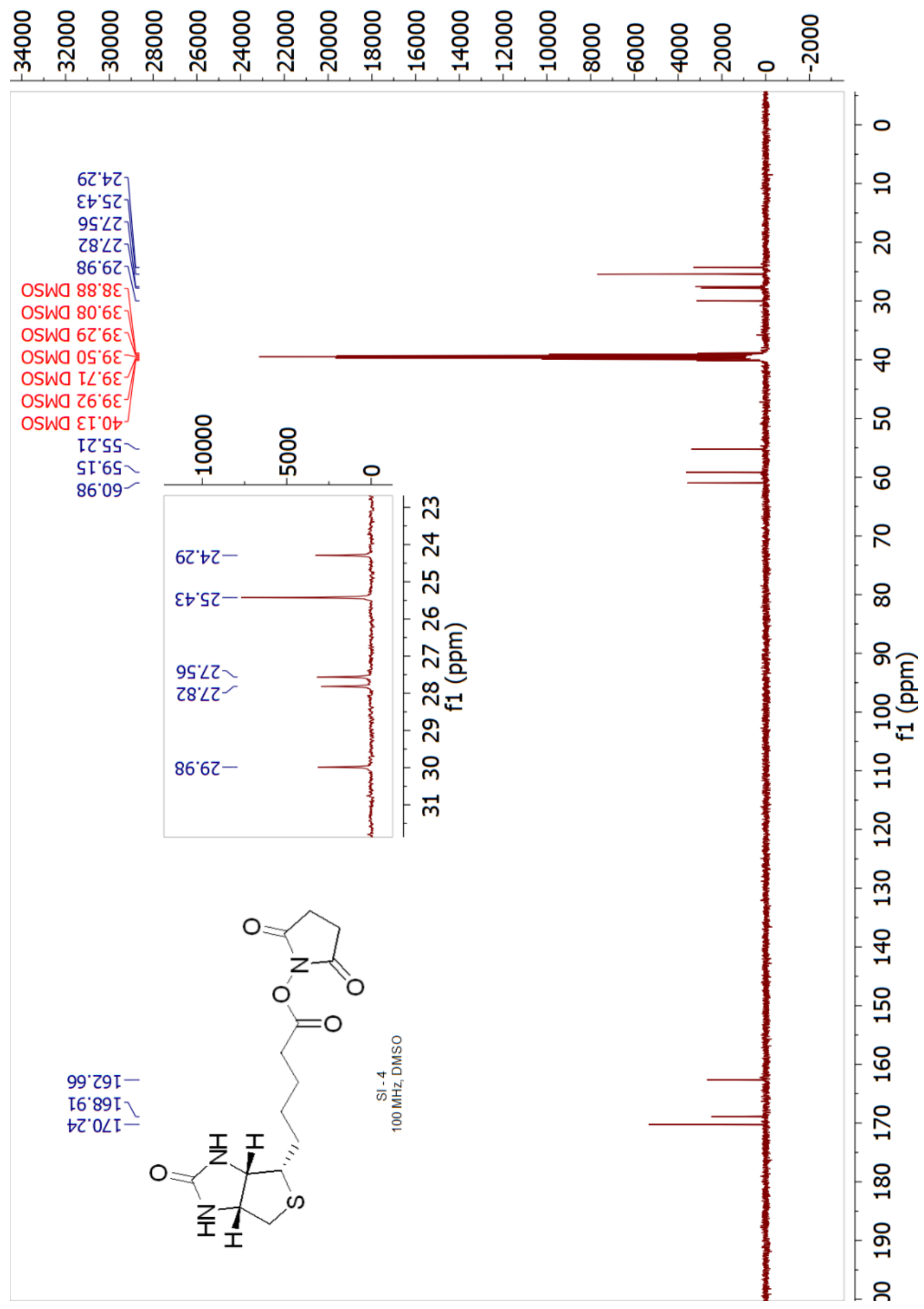


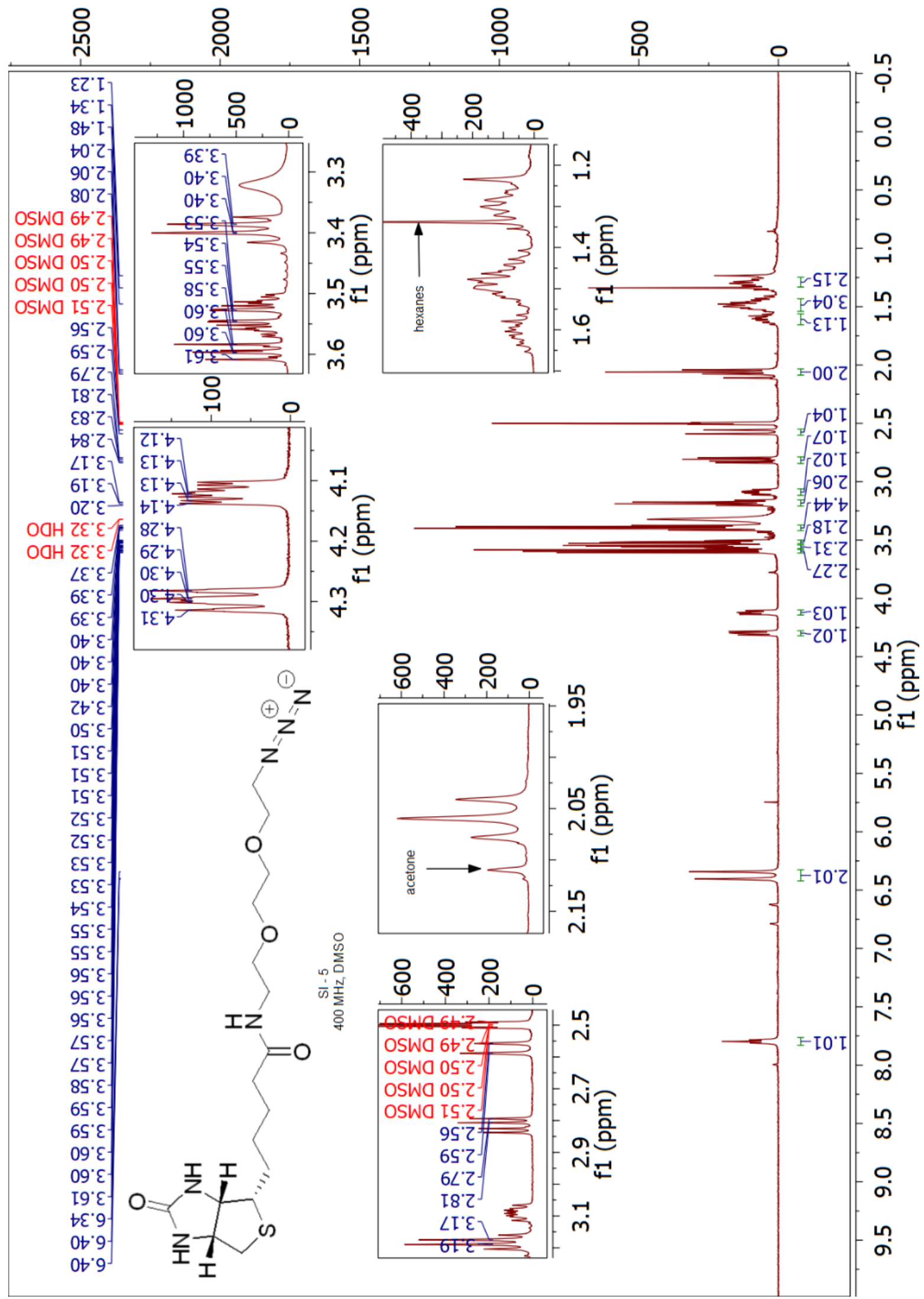



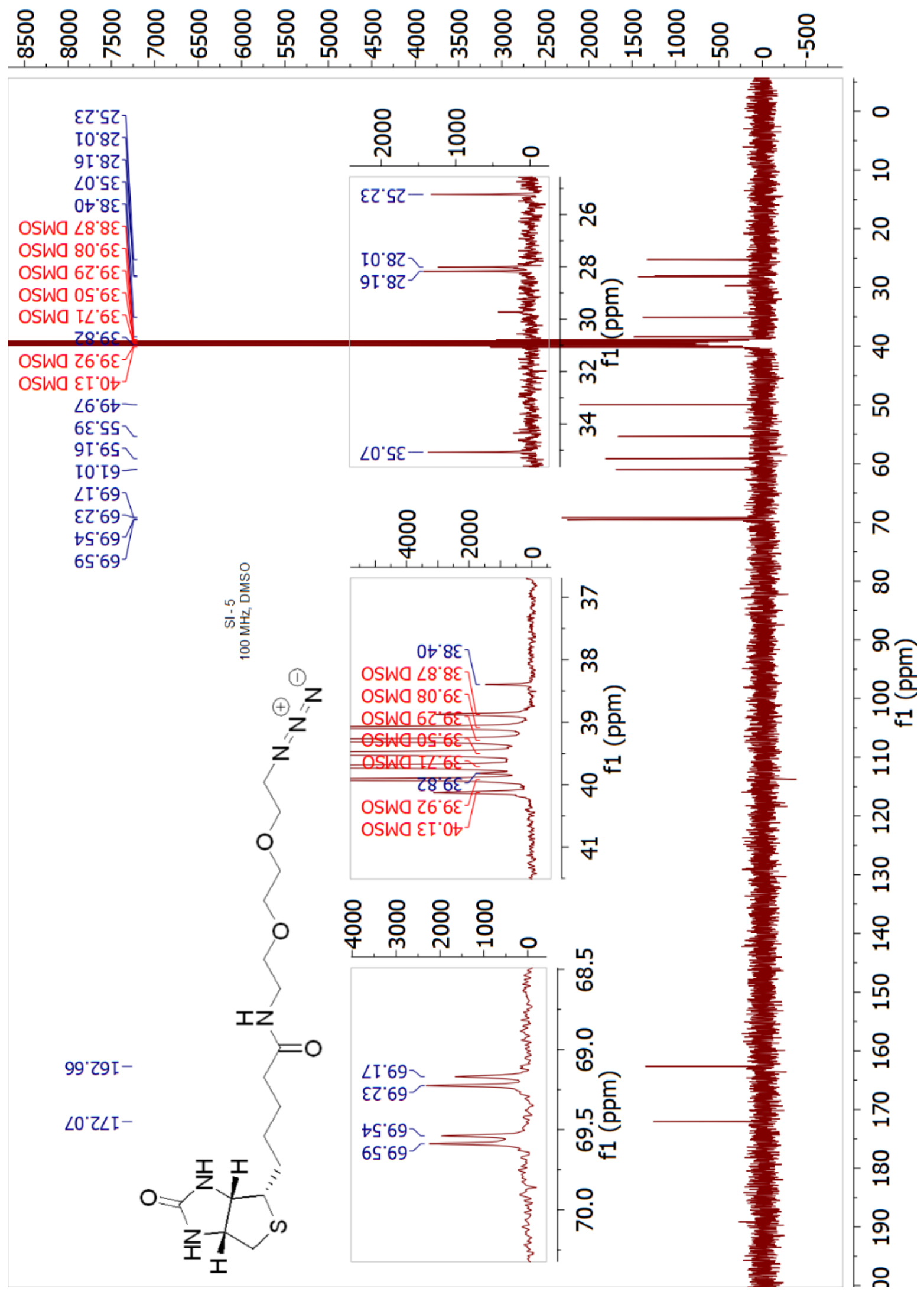